Article

\title{
Synthesis and Biological Evaluation of Novel (thio)semicarbazone-Based Benzimidazoles as Antiviral Agents against Human Respiratory Viruses
}

\author{
Valeria Francesconi ${ }^{1}$, Elena Cichero ${ }^{1}$, Silvia Schenone ${ }^{1}$, Lieve Naesens ${ }^{2} \oplus$ and \\ Michele Tonelli ${ }^{1, *(1)}$ \\ 1 Dipartimento di Farmacia, Università di Genova, Viale Benedetto XV 3, 16132 Genova, Italy; \\ francesconi.phd@difar.unige.it (V.F.); cichero@difar.unige.it (E.C.); schenone@difar.unige.it (S.S.) \\ 2 Rega Institute for Medical Research, KU Leuven, Herestraat 49, B-3000 Leuven, Belgium; \\ lieve.naesens@kuleuven.be \\ * Correspondence: tonelli@difar.unige.it; Tel.: +39-0103538378 \\ Academic Editor: Kyoko Nakagawa-Goto \\ Received: 17 February 2020; Accepted: 23 March 2020; Published: 25 March 2020
}

\begin{abstract}
Respiratory RNA viruses are responsible for recurrent acute respiratory illnesses that still represent a major medical need. Previously we developed a large variety of benzimidazole derivatives able to inhibit these viruses. Herein, two series of (thio)semicarbazone- and hydrazone-based benzimidazoles have been explored, by derivatizing 5 -acetyl benzimidazoles previously reported by us, thereby evaluating the influence of the modification on the antiviral activity. Compounds 6, 8, 16 and 17, bearing the 5-(thio)semicarbazone and 5-hydrazone functionalities in combination with the 2-benzyl ring on the benzimidazole core structure, acted as dual inhibitors of influenza A virus and human coronavirus. For respiratory syncytial virus (RSV), activity is limited to the 5-thiosemicarbazone (25) and 5-hydrazone (22) compounds carrying the 2-[(benzotriazol-1/2-yl)methyl]benzimidazole scaffold. These molecules proved to be the most effective antiviral agents, able to reach the potency profile of the licensed drug ribavirin. The molecular docking analysis explained the SAR of these compounds around their binding mode to the target RSV F protein, revealing the key contacts for further assessment. The herein-investigated benzimidazole-based derivatives may represent valuable hit compounds, deserving subsequent structural improvements towards more efficient antiviral agents for the treatment of pathologies caused by these human respiratory viruses.
\end{abstract}

Keywords: (thio)semicarbazone-based benzimidazoles; hydrazone-based benzimidazoles; anti-RSV activity; anti-influenza activity; anti-coronavirus activity; molecular modelling studies

\section{Introduction}

The benzimidazole scaffold is a structural isostere of naturally occurring nucleobases. Many approved drugs bear a benzimidazole ring as their main unit or important substructure [1,2]. Benzimidazole-based agents are also considered for antimicrobial purposes, such as antituberculosis, antiprotozoan or antiviral activities [3,4]. Maribavir, a benzimidazole riboside with strong activity against cytomegalovirus (HCMV), is undergoing Phase III evaluation (clinicaltrials.gov NCT02927067 and NCT02931539) (Figure 1). Different substitutions on the benzimidazole nucleus of maribavir were reported to entail activity against flaviviruses, HIV, hepatitis B virus, hepatitis $\mathrm{C}$ virus $(\mathrm{HCV})$ or respiratory syncytial virus (RSV) [5]. Besides, a few non-nucleoside benzimidazole derivatives interfering with RSV F protein-mediated fusion, namely, JNJ-2408068 (R-170591), BMS-433771 and TMC353121, have reached a far stage of (pre)clinical development, but have been halted after a negative outcome [6,7] (Figure 1). Two FDA-approved inhibitors of the HCV NS5A protein, pibrentasvir and 
velpatasvir, contain a benzimidazole nucleus (Figure 1). The benzimidazole derivative B5, under clinical evaluation for the treatment of neurodegenerative diseases, was shown to delay HCV infection in a humanized mouse model [8] (Figure 1). The literature further contains examples of other benzimidazole derivatives with activity against unrelated viruses, such as influenza virus or poliovirus.<smiles>CC(C)Nc1nc2cc(Cl)c(Cl)cc2n1C(O)C(O)C(O)CO</smiles><smiles>C=CCN1CCC(/N=c2/[nH]c3c(C)cccc3n2Cc2nc(C)ccc2O)CC1</smiles>

JNJ-2408068 (RSV)<smiles>Cc1ccc(CCCO)c(NCc2ccc3[nH]c(=NCCCN4CCOCC4)n(Cc4cc(O)ccc4C)c3c2)c1</smiles><smiles></smiles>

TMC353121 (RSV)

BMS-233675 (RSV)<smiles>O=c1n(Cc2nc3ccccc3n2CCCCO)c2cnccc2n1C1CC1</smiles>

BMS-433771 (RSV)
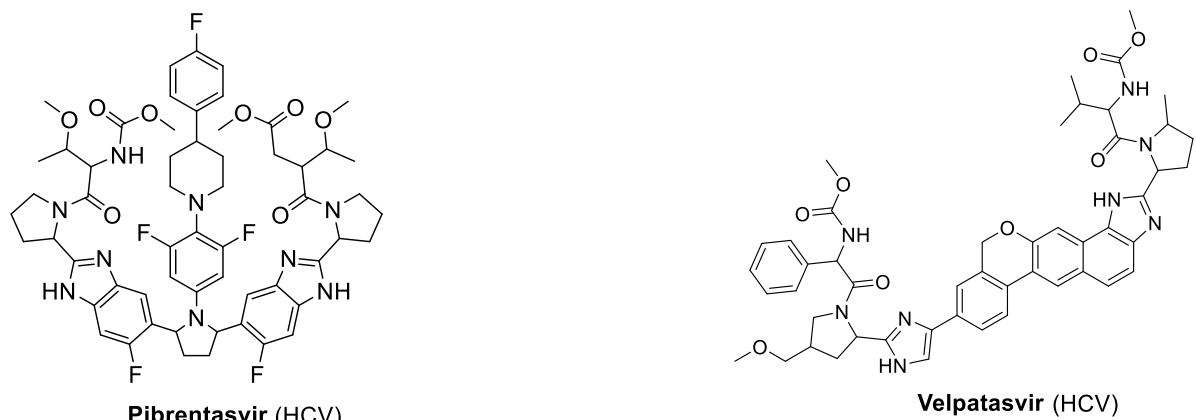

Pibrentasvir (HCV)

Velpatasvir (HCV)<smiles>CC(C)CN(CCCN1CCN(CCCNc2nc3ccccc3[nH]2)CC1)CC(C)C</smiles>

Figure 1. Some prototypic benzimidazole derivatives with activity against distinct viruses (mentioned between brackets).

Another chemical entity with relevance for antimicrobial drug development is the (thio)semicarbazone moiety. Compounds containing this structure may interfere with processes that are essential for microbe survival, such as deoxyribonucleotide synthesis, bacterial cell wall synthesis or maintenance of thiol content $[9,10]$. Interest in their antiviral properties dates back to the discovery of methysazone (Marboran ${ }^{\circledR}$ ), which was used to treat smallpox prior to its global eradication [11]. More recent studies have reported activity against other poxviruses, herpes simplex virus or influenza virus [12]. Transformation of some 5-acetyl-2-phenylbenzimidazoles into the corresponding (thio)semicarbazone analogues yielded new agents with activity against HCV and the 
related bovine viral diarrhea virus (BVDV) [13]. Inhibition of the BVDV RNA polymerase was reported for 5,6-dimethoxy-1-indanone-derived thiosemicarbazones [14].

During the few last years, we synthesized a large variety of benzimidazole-based derivatives and we explored their antitumor [15], analgesic [16] or antiviral potential. We focused on two series, i.e., 2-benzylbenzimidazoles (Series 1) [17] and 2-[(benzotriazol-1/2-yl)methyl)benzimidazoles (Series 2) $[18,19]$ 1-substituted with a basic chain. Among them, we obtained analogues with promising activity against diverse RNA viruses (Figure 2).
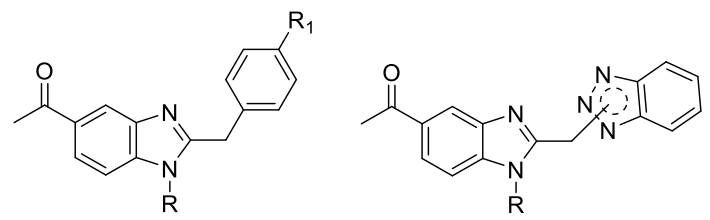

$\mathrm{R}=$ dialkylaminoalkyl, quinolizidinylalkyl

Figure 2. Scaffold structures of our Series 1 (5-acetyl substituted 2-benzylbenzimidazoles) and Series 2

(2-[(benzotriazol-1/2-yl)methyl]benzimidazoles), which we previously reported as antiviral agents.

In the light of our previous findings, we deemed it interesting to explore new additional substitution patterns on the benzimidazole main core, with the aim of gaining a better understanding of the potential of this nucleus towards the development of novel series of antiviral agents.

\section{Results and Discussion}

Since the 5-acetyl substituted benzimidazoles were generally endowed with low efficacy, we explored alternative substitutions at position 5 of the benzimidazole ring, by synthesizing (thio)semicarbazone and hydrazone derivatives (Figure 3). These new compounds were evaluated for their activities against a broad panel of viruses and cytotoxicity in several mammalian cell lines. The main results are presented in Tables 1 and 2, from which we omitted the compounds having no antiviral nor cytotoxic activity (at $100 \mu \mathrm{M}$, the highest concentration tested).

Table 1. Activities of compounds 6, 8, 16, 17, 22, 24 and 25 against three different human respiratory viruses.

\begin{tabular}{|c|c|c|c|c|}
\hline \multirow[t]{2}{*}{ Compound } & \multicolumn{4}{|c|}{ Antiviral $\mathrm{EC}_{50}{ }^{\mathrm{a}}(\mu \mathrm{M})$} \\
\hline & RSV & Influenza A/H1N1 & Influenza A/H3N2 & Coronavirus 229E \\
\hline 6 & $>100$ & 25 & 81 & 38 \\
\hline 8 & $>100$ & 38 & $>100$ & 56 \\
\hline 16 & $>100$ & 47 & $>100$ & 39 \\
\hline 17 & $>100$ & 47 & $>100$ & 41 \\
\hline $22^{b}$ & 7.0 & 41 & $>100$ & $>100$ \\
\hline 24 & $>100$ & $>100$ & $>100$ & 43 \\
\hline 25 & 2.4 & $>100$ & $>100$ & $>100$ \\
\hline Zanamivir & - & 0.6 & 31 & - \\
\hline Ribavirin & 6.7 & 7.4 & 7.5 & - \\
\hline DS- $10,000^{c}$ & 0.01 & - & - & - \\
\hline $\mathrm{UDA}^{\mathrm{c}}$ & - & - & - & 2.2 \\
\hline
\end{tabular}

${ }^{\mathrm{a}} \mathrm{EC}_{50}: 50 \%$ effective concentration or concentration giving $50 \%$ protection against virus-induced reduction in cell viability, as determined by the colorimetric formazan-based MTS assay. ${ }^{\mathrm{b}}$ This compound was also active against Coxsackie B4 virus with an $\mathrm{EC}_{50}$ value of $20 \mu \mathrm{M} .{ }^{\mathrm{c}}$ For dextran sulfate MW 10,000 (DS-10,000) and UDA lectin, concentrations are in $\mu \mathrm{g} / \mathrm{mL}$. 


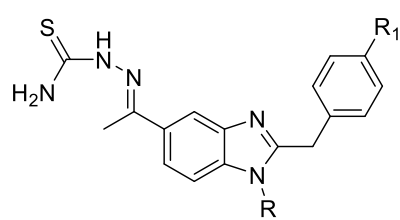

$$
\begin{aligned}
& \text { 1. } \mathrm{R}=\left(\mathrm{CH}_{2}\right)_{2} \mathrm{~N}\left(\mathrm{CH}_{3}\right)_{2} \\
& \mathrm{R}_{1}=\mathrm{OCH}_{3}
\end{aligned}
$$

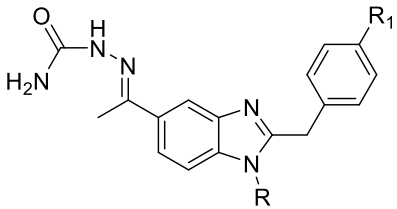

10. $\mathrm{R}=\left(\mathrm{CH}_{2}\right)_{2} \mathrm{~N}\left(\mathrm{CH}_{3}\right)_{2}$ $\mathrm{R}_{1}=\mathrm{OCH}_{3}$

11. $\mathrm{R}=\left(\mathrm{CH}_{2}\right)_{2} \mathrm{~N}\left(\mathrm{CH}_{3}\right)_{2}$ $\mathrm{R}_{1}=\mathrm{Cl}$

12. $\mathrm{R}=\left(\mathrm{CH}_{2}\right)_{2} \mathrm{~N}\left(\mathrm{CH}_{3}\right)_{2}$ $\mathrm{R}_{1}=\mathrm{OCH}_{2} \mathrm{CH}_{3}$

13. $\mathrm{R}=\left(\mathrm{CH}_{2}\right)_{3} \mathrm{~N}\left(\mathrm{CH}_{3}\right)_{2}$ $\mathrm{R}_{1}=\mathrm{Cl}$

14. $\mathrm{R}=\left(\mathrm{CH}_{2}\right)_{2} \mathrm{~N}\left(\mathrm{CH}_{2} \mathrm{CH}_{3}\right)_{2}$ $\mathrm{R}_{1}=\mathrm{OCH}_{3}$

15. $\mathrm{R}=\left(\mathrm{CH}_{2}\right)_{2} \mathrm{~N}\left(\mathrm{CH}_{2} \mathrm{CH}_{3}\right)_{2}$ $\mathrm{R}_{1}=\mathrm{Cl}$

16. $\mathrm{R}=\left(\mathrm{CH}_{2}\right)_{3} \mathrm{~N}\left(\mathrm{CH}_{2} \mathrm{CH}_{3}\right)_{2}$ $\mathrm{R}_{1}=\mathrm{H}$

17. $\mathrm{R}=\left(\mathrm{CH}_{2}\right)_{3} \mathrm{~N}\left(\mathrm{CH}_{2} \mathrm{CH}_{3}\right)_{2}$ $\mathrm{R}_{1}=\mathrm{OCH}_{3}$<smiles>[X]/C(N)=N/N=C(\C)c1ccc2c(c1)nc(Cn1nc3ccccc3n1)n2[R]</smiles>

18. $\mathrm{X}=\mathrm{S}$ $\mathrm{R}=\left(\mathrm{CH}_{2}\right)_{2} \mathrm{~N}\left(\mathrm{CH}_{3}\right)_{2}$

19. $X=S$ $\mathrm{R}=\left(\mathrm{CH}_{2}\right)_{3} \mathrm{~N}\left(\mathrm{CH}_{3}\right)_{2}$
20. $\mathrm{X}=\mathrm{O}$ $\mathrm{R}=\left(\mathrm{CH}_{2}\right)_{2} \mathrm{~N}\left(\mathrm{CH}_{3}\right)_{2}$

21. $X=S$ $\mathrm{R}=\left(\mathrm{CH}_{2}\right)_{2} \mathrm{~N}\left(\mathrm{CH}_{2} \mathrm{CH}_{3}\right)_{2}$<smiles>C/C(=N\NC(N)=S)c1ccc2c(c1)nc(Cn1nnc3ccccc31)n2CCCN(C)C</smiles><smiles>[R8]c1ccc(Cc2nc3cc(/C(C)=N/N)ccc3n2[R])cc1</smiles>

23. $\mathrm{R}=\left(\mathrm{CH}_{2}\right)_{2} \mathrm{~N}\left(\mathrm{CH}_{3}\right)_{2}$ $\mathrm{R}_{1}=\mathrm{OCH}_{3}$

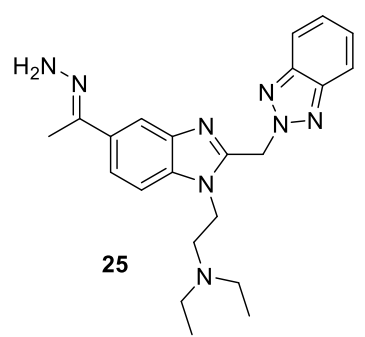

24. $\mathrm{R}=\left(\mathrm{CH}_{2}\right)_{2} \mathrm{~N}\left(\mathrm{CH}_{2} \mathrm{CH}_{3}\right)_{2}$ $\mathrm{R}_{1}=\mathrm{OCH}_{2} \mathrm{CH}_{3}$

Figure 3. Chemical structures of the novel (thio)semicarbazone- and hydrazone-incorporating benzimidazoles (1-25).

These investigations were accompanied by docking studies of the title compounds in complex with the RSV fusion F protein, which allowed the identification of the most relevant features involved in the protein-inhibitor recognition. 
Table 2. Cytotoxicity of compounds 6, 8, 16, 17, 22, 24 and 25 in four mammalian cell lines.

\begin{tabular}{ccccc}
\hline \multirow{2}{*}{ Compound } & \multicolumn{4}{c}{$\mathrm{CC}_{\mathbf{5 0}}{ }^{\mathbf{a}}(\boldsymbol{\mu M})$} \\
\cline { 2 - 5 } & Hep-2 & HEL & Vero & MDCK \\
\hline $\mathbf{6}$ & $>100$ & $>100$ & $>100$ & $>100$ \\
$\mathbf{8}$ & $>100$ & $>100$ & 44 & $>100$ \\
$\mathbf{1 6}$ & $>100$ & $>100$ & $>100$ & $>100$ \\
$\mathbf{1 7}$ & 48 & $>100$ & 43 & $>100$ \\
$\mathbf{2 2}$ & $>100$ & 100 & $>100$ & $>100$ \\
$\mathbf{2 4}$ & $>100$ & $>100$ & 51 & 35 \\
$\mathbf{2 5}$ & $>100$ & $>100$ & $>100$ & 33 \\
Zanamivir $_{\text {Ribavirin }}$ & - & - & - & $>100$ \\
DS-10,000 $^{\mathrm{b}}$ & $>250$ & - & $>250$ & $>100$ \\
UDA $^{\mathrm{b}}$ & - & - & $>100$ & - \\
\end{tabular}

${ }^{a} \mathrm{CC}_{50}: 50 \%$ cytotoxic concentration based on the MTS cell viability assay. Hep-2: human epithelial type 2 cells; HEL: human embryonic lung fibroblast cells; Vero: African green monkey kidney cells; MDCK: Madin-Darby canine kidney cells. ${ }^{b}$ For dextran sulfate MW 10,000 (DS-10,000) and UDA lectin, concentrations are in $\mu \mathrm{g} / \mathrm{mL}$.

\subsection{Chemistry}

The starting 5-acetyl-2-benzylbenzimidazoles (Series 1) have been synthesized according to the literature [20], by the reaction of the proper 4-acetyl-1,2-phenylenediamine with the hydrochloride of the iminoester, previously obtained from the corresponding nitrile under Pinner conditions. The condensation at $180{ }^{\circ} \mathrm{C}$ of a mixture of the proper 1,2-phenylenediamine with the (benzotriazol-1/2-yl)acetic acid has given the 5-acetyl-2-[(benzotriazol-1/2-yl)methyl]benzimidazoles [21].

Our target compounds 1-25 have been obtained following the synthetic routes presented in Schemes 1 and 2. Thiosemicarbazones 1-9, 18, 19, 21 and 22, and semicarbazones 10-17 and 20 have been prepared by refluxing an ethanolic/aqueous solution of thiosemicarbazide or semicarbazide hydrochloride in the presence of glacial acetic acid or sodium acetate, respectively.
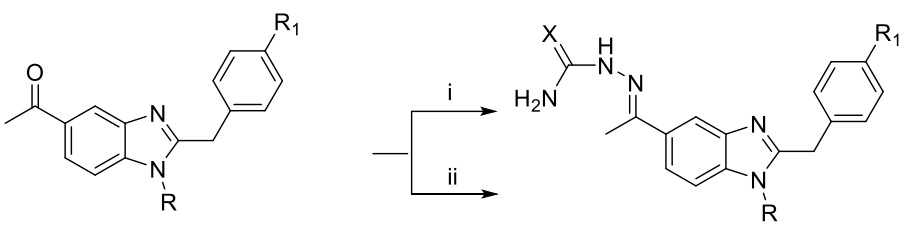

$$
\begin{aligned}
\mathrm{R}= & \left(\mathrm{CH}_{2}\right)_{2} \mathrm{~N}\left(\mathrm{CH}_{3}\right)_{2},\left(\mathrm{CH}_{2}\right)_{3} \mathrm{~N}\left(\mathrm{CH}_{3}\right)_{2} \\
& \left(\mathrm{CH}_{2}\right)_{2} \mathrm{~N}\left(\mathrm{C}_{2} \mathrm{H}_{5}\right)_{2},\left(\mathrm{CH}_{2}\right)_{3} \mathrm{~N}\left(\mathrm{C}_{2} \mathrm{H}_{5}\right)_{2} \\
\mathrm{R}_{1}= & \mathrm{H}, \mathrm{OCH}_{3}, \mathrm{OC}_{2} \mathrm{H}_{5}, \mathrm{Cl}
\end{aligned}
$$$$
1-17
$$

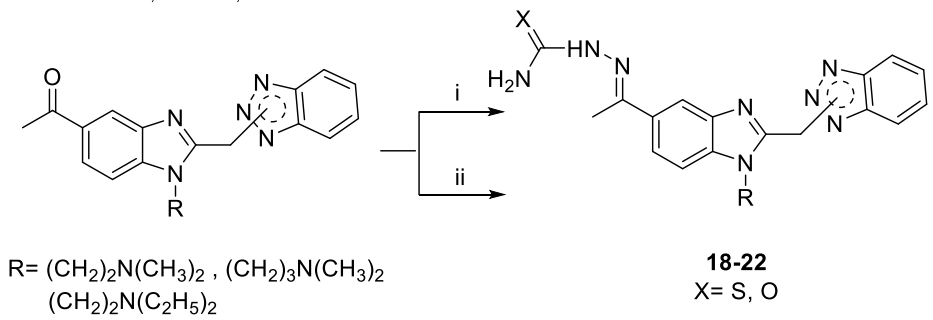

Scheme 1. Reagents and conditions: (i) thiosemicarbazide in $\mathrm{EtOH}, \mathrm{H}_{2} \mathrm{O}$ and glacial $\mathrm{CH}_{3} \mathrm{COOH}, 3 \mathrm{~h}$ at reflux; (ii) semicarbazide $\cdot \mathrm{HCl}$ in $\mathrm{EtOH}$ and $\mathrm{CH}_{3} \mathrm{COONa} 1 \mathrm{~N}, 4 \mathrm{~h}$ at reflux. 


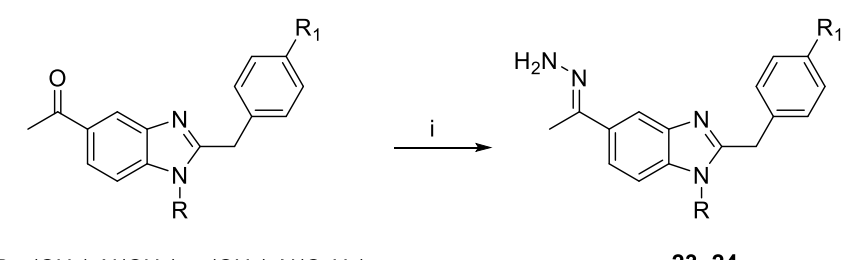

$\mathrm{R}=\left(\mathrm{CH}_{2}\right)_{2} \mathrm{~N}\left(\mathrm{CH}_{3}\right)_{2},\left(\mathrm{CH}_{2}\right)_{2} \mathrm{~N}\left(\mathrm{C}_{2} \mathrm{H}_{5}\right)_{2}$

23,24

$\mathrm{R}_{1}=\mathrm{OCH}_{3}, \mathrm{OC}_{2} \mathrm{H}_{5}$,

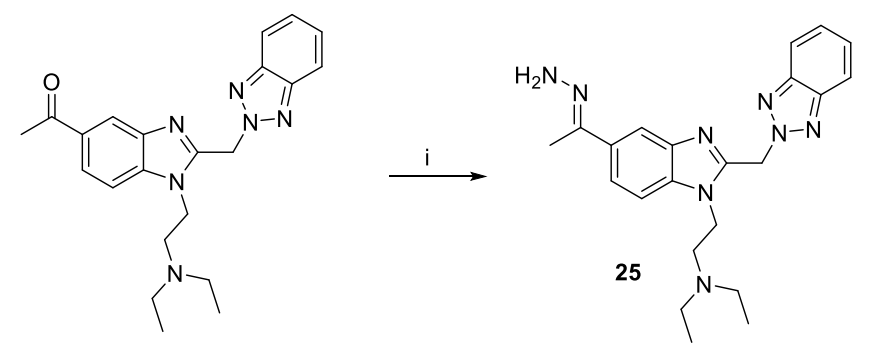

Scheme 2. Reagents and conditions: (i) $\mathrm{EtOH} / \mathrm{H}_{2} \mathrm{O}, \mathrm{NH}_{2} \mathrm{NH}_{2} \cdot \mathrm{H}_{2} \mathrm{O}\left(1.15\right.$ equiv.), $120{ }^{\circ} \mathrm{C}, 5$ h.3.

The reaction at reflux of the proper 5-acetyl benzimidazole with a slight excess of hydrazine hydrate for $5 \mathrm{~h}$ has afforded the target hydrazone derivatives 23-25 (Scheme 2). The structures of the novel compounds have been confirmed using ${ }^{1} \mathrm{H}$ and ${ }^{13} \mathrm{C} N M R$, and elemental analysis. The purity of compounds (checked by elemental analysis) has been in all cases $>95 \%$.

Thiosemicarbazones are known to display thione-thiol tautomerism, since they contain the hydrazidic proton $(-\mathrm{C}(=\mathrm{S}) \mathrm{NH}-\mathrm{N}=)$ that can shift onto the sulfur atom, leading to a thiol form stabilized by conjugation $(-\mathrm{C}(-\mathrm{SH})=\mathrm{N}-\mathrm{N}=)$. Indeed, on the $1 \mathrm{H}$ NMR spectra our compounds do not exhibit the signal at $4.00 \mathrm{ppm}$, attributable to -SH proton, suggesting that the thione form is the only tautomer. The Schiff base of our thiosemicarbazone moiety acquires $\mathrm{E}$ isomerism since the hydrazinic proton $(-\mathrm{C}(=\mathrm{S}) \mathrm{NH}-\mathrm{N}=)$ falls in the 9-12 ppm range [22]. In fact this signal appears at ca $10.18 \mathrm{ppm}$, whilst the thioamide protons $\left(-\mathrm{C}(=\mathrm{S}) \mathrm{NH}_{2}\right)$ exhibit two different chemical shifts at ca $8.25 \mathrm{ppm}$ and 7.94 ppm. The same consideration can be made for semicarbazones with the exception of the signal of amide group $\left(\mathrm{CONH}_{2}\right)$ which appears as a broad singlet $(\mathrm{ca} 6.50 \mathrm{ppm})$ with the two protons being indistinguishable. The different behaviors of the two series may be explained by the restricted free rotation brought about by the formation of the carbon-nitrogen double bond character relative to thione-thiol tautomerism [23]. In addition, it is noteworthy that the sulfur atom of the thione tautomer has a greater atomic radius than oxygen atom of the corresponding semicarbazone, thereby making the thioamide protons magnetically different for steric hindrance.

\subsection{Biological Evaluation $S A R$}

As explained above, the new compounds were synthesized from 5-acetyl substituted 2-benzylbenzimidazoles and 2-[(benzotriazol-1/2-yl)methyl]benzimidazoles (Series 1 and 2; Figure 2). We previously published that Series 2 has high potential against RSV, with the best performing derivatives having nanomolar activity $[18,19]$. These compounds carried at position 1 of the benzimidazole ring different basic chains, such as the most efficacious quinolizidinylalkyl [(octahydro-2H-quinolizin-1-yl)alkyl] chains or the dialkylaminoalkyl ones $[18,19]$.

The new compounds (1-25) were evaluated against a broad panel of RNA and DNA viruses in suitable mammalian cell culture assays [24-27]. The antiviral activity data obtained by microscopic inspection of the viral CPE (data not shown) were in agreement with those obtained by the colorimetric MTS cell viability test (Table 1). The most active compounds 22 and 25 exhibited $\mathrm{EC}_{50}$ values of 7.0 and $2.4 \mu \mathrm{M}$ in the MTS method, versus 8.9 and $2.4 \mu \mathrm{M}$ in the microscopic method.

Seven compounds displayed activity against one of more human respiratory viruses; i.e., RSV (22 and 25), influenza A virus $(\mathbf{6}, \mathbf{8}, \mathbf{1 6}, 17$ and 22) or human coronavirus $(\mathbf{6}, \mathbf{8}, \mathbf{1 6}, \mathbf{1 7}$ and 24) (Table 1). 
Compounds 22 and 25 had anti-RSV $\mathrm{EC}_{50}$ values of 7.0 and $2.4 \mu \mathrm{M}$, respectively, which makes them equipotent to the reference drug ribavirin $\left(\mathrm{EC}_{50}\right.$ of $\left.6.7 \mu \mathrm{M}\right)$. A lower level of activity was seen for influenza $\mathrm{A}$ and coronavirus, with the $\mathrm{EC}_{50}$ values falling in the range of $25-86 \mu \mathrm{M}$. Despite this relatively weak activity, it is relevant to note that compounds 6, 8, 16, 17 and 24 are the first benzimidazole derivatives reported as active against coronavirus.

The following careful SAR analysis could be made. For RSV, activity is restricted to the 5-(thio)semicarbazone (25) and hydrazone (22) compounds carrying the 2-[(benzotriazol-1/2-yl)methyl]benzimidazole scaffold, in line with the previously synthesized analogues (see above), which show comparable potency in the low micromolar range.

Regarding influenza A and coronaviruses, the activity is promoted by (thio)semicarbazone and hydrazone functionalities, especially when combined with the benzyl ring $(6,8,16,17$ and 24) compared to the bulkier (benzotriazol-1/2-yl)methyl skeleton (22). The nature of the substituent in the para position of the benzyl ring $\left(\mathrm{H}, \mathrm{Cl}, \mathrm{OCH}_{3}\right)$ does not seem to have significant impact on the antiviral activity, since the unsubstituted derivatives $\left(\mathbf{8}, \mathbf{1 6} ; \mathrm{R}_{1}=\mathrm{H}\right)$ had comparable potency of those decorated with electron-withdrawing $\left(\mathbf{6} ; \mathrm{R}_{1}=\mathrm{Cl}\right)$ or electron-donor groups $\left(\mathbf{1 7} ; \mathrm{R}_{1}=\mathrm{OCH}_{3}\right)$.

Finally, most compounds were devoid of cytotoxicity at $100 \mu \mathrm{M}$, the highest concentration tested. Two compounds, $\mathbf{1 7}$ and 24, produced cytotoxicity in two of the four cell lines. The other molecules were either not toxic or exhibited a $\mathrm{CC}_{50}$ value of about $50 \mu \mathrm{M}$ in one of the four cell lines.

Interestingly, influenza A and human coronavirus shared sensitivity to the same inhibitors, 6, 8, 16 and 17 , whose definition of the mechanism of action is beyond the scope of this exploratory work.

As is well-known from literature, the antiviral activity against RSV is limited to several benzimidazole derivatives (Figure 1) [28,29], and also to the more recent analogue JNJ-53718678 (Figure 4) [30], which were demonstrated to impair the viral replication machinery by blocking the F protein-induced membrane fusion. From 2017, JNJ-53718678 entered Phase 2 studies in adults and infants for therapy of RSV infections (ClinicalTrials.gov Identifier NCT03379675, NCT03656510, NCT04056611). Due to the substantial structural similarity between the newly synthesized compounds and the above anti-RSV (pre)clinical candidates, molecular modeling studies were performed in order to reveal the most important features underlying the F protein/ligand interactions.

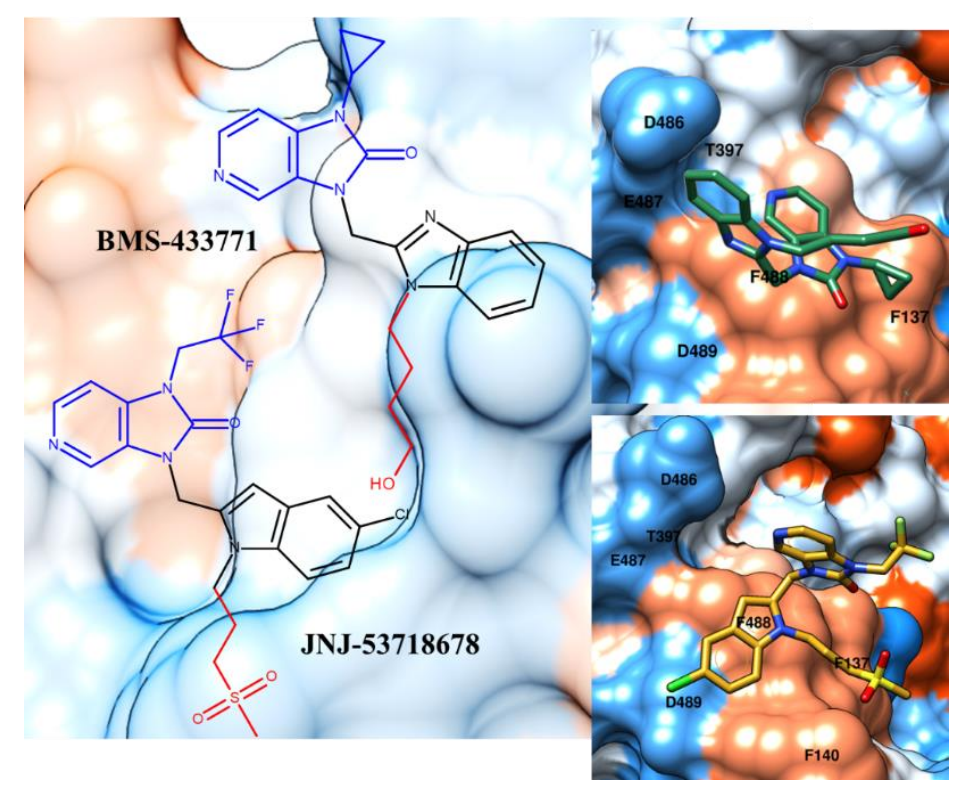

Figure 4. Chemical structure and X-ray positioning of BMS-433771 (pdb code: 5EA7) [31] and JNJ-53718678 (pdb code: 5KWW) [32] in complex with the RSV F protein. The chemical motifs of the two inhibitors featuring quite comparable contacts with the biological target are highlighted in blue and red. Hydrophobic and polar areas of the protein are represented as blue and orange regions on the RSV F protein's Connolly surface. 


\subsection{Molecular Modelling Studies}

During the last few years, a number of crystallographic structures of the prefusion RSV glycoprotein became available focusing on several benzimidazole-based or bioisosteres inhibitors as co-crystallized ligands [31-33]. A number of them highlighted a small number of contacts responsible for the inhibitor positioning at the exposed surface area of the protein, occupying one hydrophobic region of the biological target especially, including the F137 residue. As shown in Figure 4, the inhibitors BMS-433771 and JNJ-53718678 move the 1,3-dihydroimidazo[4,5-c]pyridin-2-one ring into the proximity of the aforementioned F137 and F488 amino acids, detecting the first one $\pi-\pi$ stacking with these residues. The substitution of the alkoxy chain of BMS-433771 with the JNJ-53718678 sulfone moiety makes the compound more hydrophobic than the prototype, flatting the JNJ-53718678 indole core towards F137, F140 and F488.

Interestingly, the presence of the alkyl-morpholine chain linked to the dihydrobenzimidazole core of the compound TMC353121 allowed us to explore another RSV F protein binding pocket, which is able to anchor the inhibitor at the exposed surface of the protein (see Figure 5).

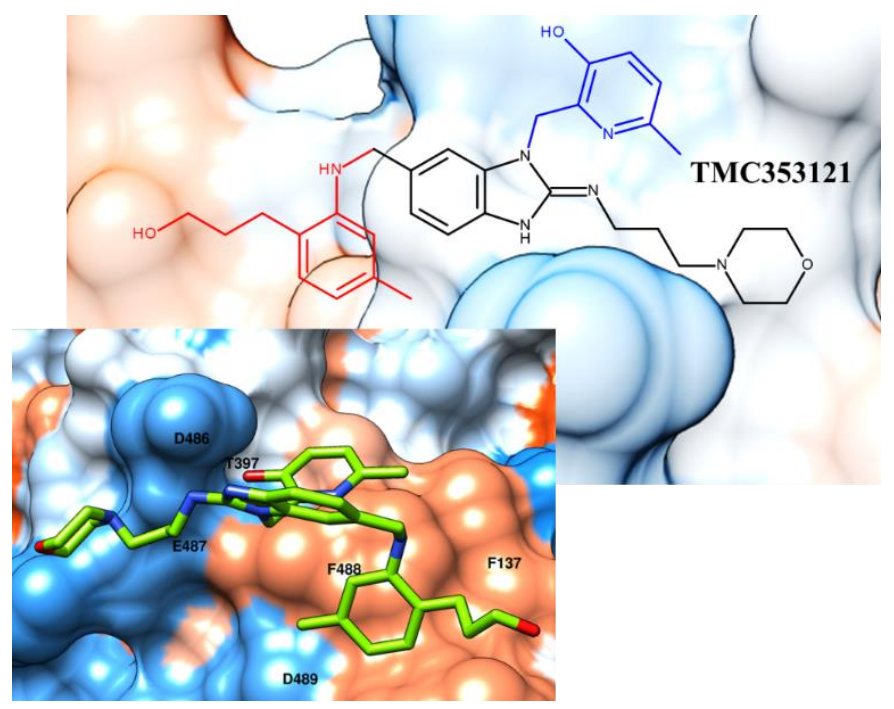

Figure 5. Chemical structure and X-ray positioning of TMC353121 (pdb code: 5EA5) [31] in complex with the RSV F protein. The chemical motif of the inhibitor maintained the key contacts displayed by the analogues BMS-433771 and JNJ-53718678; they are highlighted in blue and red. Hydrophobic and polar areas of the protein are represented as blue and orange regions on the RSV F protein's Connolly surface.

Indeed, the X-ray crystallographic data of this ligand in complex with the F protein reveal polar contacts between the TMC353121 protonated nitrogen atom of the morpholine ring and a polar area of the protein, including D486 and E487. On the other hand, the pyridine group and the terminal phenyl ring were properly oriented toward T397, detecting one H-bond with the biological target, and around the hydrophobic pocket previously discussed for BMS-433771 and JNJ-53718678 characterized by F137 and F488. On this basis, it is thought that interactions with F137 are mandatory to exert RSV F protein inhibition; the most promising compounds are better stabilized at the surface of the protein by additional $\mathrm{H}$-bonds with the near polar pocket.

Herein we discuss this computational work with the aim of exploring an adequate RSV F protein inhibition activity of the newly synthesized antiviral compounds, by means of molecular docking simulations taking into account the X-ray crystallographic structure of the RSV F protein in complex with JNJ-53718678 (pdb code $=5 \mathrm{KWW}$; resolution $=2.5 \AA$ ) [32]. This crystallographic data have been chosen based on the structural similarity shown by the reference compound JNJ-53718678 with the in-house, benzimidazole-based hydrazones and thiosemicarbazones. Currently, JNJ-53718678 is the 
more promising clinical candidate, whose potential therapeutic is undergoing evaluation in patients at high risk to developing acute RSV lower respiratory tract infections (ClinicalTrials.gov Identifier NCT03379675, NCT03656510, NCT04056611).

The main issues to be addressed were to clarify the role played by the hydrazone moiety and by the thiosemicarbazone at the position five of benzimidazole main core, especially when accompanied by a benzyl or a benzotriazole-1-yl or benzotriazole-2-yl ring linked at position 2 of the inhibitor scaffold. This was done through docking studies of all the newly synthesized compounds. According to our calculations (Table 3), only compounds 22 and 25 properly bind the exposed surface of the RSV F protein - they are anchored in the hydrophobic pocket by $\pi-\pi$ stacking and cation- $\pi$ interactions with F137, F140 and F488.

Table 3. Binding affinity values obtained by molecular docking studies of the compounds JNJ-53718678,

$4,19,21,22,24$ and 25.

\begin{tabular}{cccc}
\hline $\begin{array}{c}\text { Protein-Ligand } \\
\text { Complex (LeadIT) }\end{array}$ & $\begin{array}{c}\text { Binding Affinity Energy } \\
\mathbf{\Delta G} \mathbf{( k J / m o l )}\end{array}$ & $\begin{array}{c}\text { Protein-Ligand } \\
\text { Complex (LeadIT) }\end{array}$ & $\begin{array}{c}\text { Binding Affinity Energy } \\
\boldsymbol{\Delta G} \mathbf{( k J} / \mathbf{m o l})\end{array}$ \\
\hline 5 KWW- JNJ-53718678 & -25.0 & $5 K W W-22$ & -19.0 \\
$5 K W W-4$ & -3.0 & $5 K W W-24$ & -1.0 \\
$5 K W W-19$ & -5.0 & $5 K W W-25$ & -20.0 \\
$5 K W W-21$ & -13.0 & & \\
\hline
\end{tabular}

As shown in Figure 6, both the inhibitors moved the benzimidazole core in proximity of the aforementioned aromatic residues ( $\pi-\pi$ interactions) while the hydrazone group of 25 and the protonated amine chain of 22 were projected near F137, featuring cation- $\pi$ stacking and H-bonds with the oxygen atom of the F137 carbonyl group.
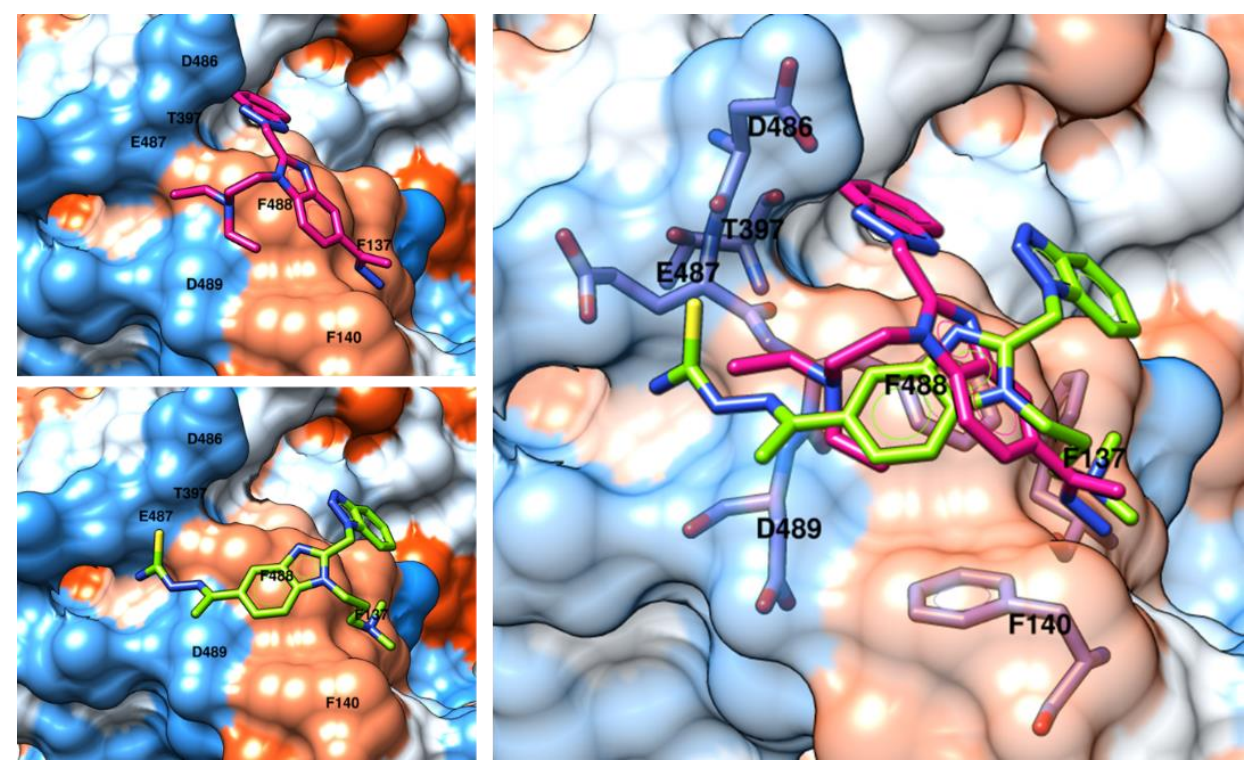

Figure 6. X-ray crystallographic data of the RSV F protein (pdb code: 5KWW; C atom; purple). Docking positioning of the inhibitors 22 and 25 (C atom; green and deep magenta, respectively) are shown within the surface of the protein (left side). Superimposition of the docking poses of 22 and 25 are shown on the right side. The most important residues are labelled and colored by atom type.

Notably, the replacement of the hydrazone group of 25 with the thiosemicarbazone moiety of 22 switched the positioning of the inhibitor 22, moving it the thiosemicarbazone moiety and the amine chain near the amine group and the hydrazone function of the analogue 25; we detected comparable contacts with E437 and F137, respectively. Changing the benzotriazol-2-yl ring of 25 with the benzotriazol-1-yl one of 22 quite shifts the overall positioning of this portion of the molecule, even if 
it was oriented towards the same pocket. Interestingly, the benzotriazol-2-yl ring of 25 was H-bonded to the T397 side-chain.

While maintaining the hydrazone moiety in tandem with the substitution of the benzotriazolyl group with a decorated phenyl one led to the inactive compound 24, unable to be stabilized at the surface of the protein, the replacement of the hydrazone group with the thiosemicarbazone one led to the analogue 21. Interestingly, this featured H-bonds between the thiosemicarbazone function and E487, while the benzotriazolyl group and the amine chain moved far from the corresponding heteroaromatic group and hydrazone moiety of the analogue 25 (see Figure S1). On the other hand, even if this kind of positioning was in agreement with that previously discussed for the effective analogue 22, it was unable to detect the same contacts displayed by 22 probably because of the different docking mode driven by the benzotriazol-1-yl skeleton in place of the benzotriazole-2-yl one of 25 . Accordingly, compound 19 exhibited a comparable docking mode with that of the analogue 21, lacking the key contacts with F137 at the thiosemicarbazone moiety or amine chain group (Figure S2). Finally, the introduction of the smaller phenyl ring instead of the benzotriazolyl core at position two of the benzimidazole main ring (compound 4) moved the amine chain towards the protein's deep crevice delimited by T397 while the phenyl moiety detected $\pi-\pi$ stacking with F137, missing any H-bonds with this residue. Conversely, the thiosemicarbazone group was H-bonded to E487 (see Figure S3). Accordingly, this compound was poorly effective if compared with the analogue 22.

In this work we also evaluated, by computational prediction, a number of descriptors related to absorption, distribution, metabolism and excretion properties (ADME). This represents a useful in silico strategy for accelerating the discovery of drug-like compounds [33]. For the most promising antiviral compounds, 22 and 25, we calculated the number of H-bonding acceptor and donor groups and rotable bonds, the logarithmic ratio of the octanol-water partitioning coefficient (cLogP), the human intestinal absorption (HIA), the volume of distribution (Vd), the binding to plasmatic proteins (\%PPB) and albumin (LogKa HSA) and the oral bioavailability percentage (\%F). As shown in Table 4, all the compounds were characterized by a favorable profile in terms of lipophilicity-that being an LogP below 5 (Lipinski rules) - and also displayed the ability to be fully adsorbed at the human intestinal membrane. With respect to the reference compound, 22 and 25 featured higher oral bioavailability and lower binding to plasmatic proteins.

Table 4. Absorption, distribution, metabolism and excretion (ADME) descriptors related to absorption and distribution properties.

\begin{tabular}{|c|c|c|c|c|c|c|c|c|c|}
\hline Comp. & $\begin{array}{l}\text { N. H-Bond } \\
\text { acceptor }\end{array}$ & $\begin{array}{l}\text { N. H-Bond } \\
\text { donor }\end{array}$ & $\begin{array}{l}\text { N. Rotable } \\
\text { Bonds }\end{array}$ & cLogP & $\begin{array}{l}\text { HIA } \\
(\%)^{a}\end{array}$ & $\begin{array}{c}\text { Vd } \\
(1 / \mathrm{kg})^{b}\end{array}$ & $\%$ PPB $^{c}$ & $\begin{array}{c}d \\
\operatorname{LogK}_{a}{ }^{H S A}\end{array}$ & $\begin{array}{c}\% \mathrm{~F} \\
\text { (oral) }\end{array}$ \\
\hline JNJ-53718678 & 7 & 0 & 8 & 3.36 & 100 & 2.4 & 99.0 & 5.42 & 21.0 \\
\hline 22 & 9 & 3 & 9 & 2.81 & 100 & 4.1 & 93.0 & 3.81 & 97.0 \\
\hline 25 & 8 & 2 & 8 & 3.53 & 100 & 7.0 & 93.0 & 4.34 & 99.1 \\
\hline
\end{tabular}

${ }^{a}$ HIA represents the human intestinal absorption, expressed as percentage of the molecule able to pass through the intestinal membrane; ${ }^{b}$ prediction of volume of distribution (Vd) of the compound in the body, ${ }^{c}$ percentage of compound bound to plasmatic protein, ${ }^{\mathrm{d}}$ affinity for albumin.

Docking studies allowed us to rationalize the SAR observed in these anti-RSV benzimidazoles and to recognize the compounds 25 and 22 as the best suited F protein inhibitors. The preliminary information concerning their pharmacokinetic properties pointed to a favorable drug-like profile, enabling these anti-RSV agents to undergo a further optimization process. 


\section{Materials and Methods}

\subsection{Chemistry}

\subsubsection{General Information}

Chemicals, solvents and reagents were used as obtained from commercial sources (Alfa Aesar and Sigma-Aldrich) without further purification. Column chromatography (CC): silica gel $\left(\mathrm{SiO}_{2}\right)$ (Merck). Mps: Büchi apparatus, uncorrected. ${ }^{1} \mathrm{H}$ NMR and ${ }^{13} \mathrm{C}$ NMR spectra were recorded on Varian Gemini-200 spectrometer using DMSO- $d_{6}$ as a solvent. The chemical shifts $(\delta)$ in ppm were measured relative to tetramethylsilane (TMS). $J$ in Hz. Elemental analyses were performed on Flash 2000 CHNS (Thermo Scientific) instrument in the Microanalysis Laboratory of the Department of Pharmacy, University of Genoa. Benz = benzimidazole ring; Bzt = benzotriazole ring; Arom = phenyl ring.

\subsubsection{General Procedure for the Preparation of Thiosemicarbazones}

To a solution of the proper 5 -acetyl benzimidazole $(0.80 \mathrm{mmol})$ in ethanol $(2 \mathrm{~mL})$, a solution of thiosemicarbazide $(0.85 \mathrm{mmol})$ in water $(2.8 \mathrm{~mL})$ and glacial acetic acid $(0.22 \mathrm{~mL})$ was added. The mixture was refluxed for $3 \mathrm{~h}$ under stirring. The reaction mixture was then evaporated under vacuum, yielding an oily residue that was treated with warm water to get rid of the remaining thiosemicarbazide. The crude was purified by $\mathrm{CC}\left(\mathrm{SiO}_{2}, \mathrm{CH}_{2} \mathrm{Cl}_{2}+5 \%\right.$ DEA), affording the final product as a white solid.

2-(1-\{1-[2-(N,N-Dimethylamino)ethyl]-2-(4-methoxybenzyl)-1H-benzo[d]imidazol-5-yl\}-

ethylidene)hydrazine-1-carbothioamide (1): Yield: $36 \%$ m.p. $\quad{ }_{183-84}^{\circ} \mathrm{C} .{ }^{1} \mathrm{H}$ NMR (200 MHz, DMSO-d $_{6}$ : 10.18 (s, 1H, NH), 8.24 (s, 1H, NH ), 8.16 (s, 1H, H(4)benz.), 8.00-7.83 (m, 1H, $\mathrm{H}(7)$ benz.), 7.98 (s superimposed, $\left.1 \mathrm{H}, \mathrm{NH}_{2}\right), 7.44(\mathrm{~d}, J=8.6 \mathrm{~Hz}, 1 \mathrm{H}, \mathrm{H}(6)$ benz.), $7.24(\mathrm{~d}, J=8.6 \mathrm{~Hz}, 2 \mathrm{H}$, $\mathrm{H}\left(3^{\prime}, 5^{\prime}\right.$ )arom.), 6.90 (d, $J=8.6 \mathrm{~Hz}, 2 \mathrm{H}, \mathrm{H}\left(2^{\prime}, 6^{\prime}\right)$ arom. $), 4.32-4.08\left(\mathrm{~m}, 4 \mathrm{H}, \mathrm{CH}_{2}-\mathrm{Ar}\right.$ and $\left.\mathrm{CH}_{2} \mathrm{CH}_{2}-\mathrm{N}\left(\mathrm{CH}_{3}\right)_{2}\right)$, $3.74\left(\mathrm{~s}, 3 \mathrm{H},-\mathrm{OCH}_{3}\right.$ ), 2.38 (pseudo s, 5H, 3H CH $3 \mathrm{C}=\mathrm{N}-$ and $\left.2 \mathrm{H}, \mathrm{CH}_{2} \mathrm{CH}_{2}-\mathrm{N}\left(\mathrm{CH}_{3}\right)_{2}\right), 2.13(\mathrm{~s}, 6 \mathrm{H}$, $\left.\mathrm{N}\left(\mathrm{CH}_{3}\right)_{2}\right) .{ }^{13} \mathrm{C}-\mathrm{NMR}\left(50 \mathrm{MHz}, \mathrm{DMSO}-d_{6}\right): 178.13,157.63,154.48,148.55,141.98,135.97,131.00$ (2C), 129.38 (2C), 128.22, 120.46, 116.96, 113.57 (2C), 109.37, 54.67, 45.00 (2C), 41.09, 31.88, 13.99. Analysis calculated for $\mathrm{C}_{22} \mathrm{H}_{28} \mathrm{~N}_{6} \mathrm{OS}$ \% \% $62.24, \mathrm{H} 6.65, \mathrm{~N}$ 19.79, S 7.55; found: \% C 62.44, H 6.67, N 19.80, S 7.16.

2-\{1-[2-(4-Chlorobenzyl)-1-[2-(N,N-dimethylamino)ethyl]-1H-benzo[d]imidazol-5-yl]-

ethylidene\}hydrazine-1-carbothioamide (2): Yield: $42 \%$; m.p. $\quad 199-200.5{ }^{\circ} \mathrm{C} .{ }^{1} \mathrm{H}$ NMR (200 MHz, DMSO-d $): 10.18$ (s, 1H, NH), 8.24 (s, 1H, NH 2$), 8.12$ (s, 1H, H(4)benz.), 7.97 (s superimposed, $1 \mathrm{H}, \mathrm{NH}_{2}$ ), 7.93 (d superimposed, $J=9.2 \mathrm{~Hz}, 1 \mathrm{H}, \mathrm{H}(7)$ benz.), 7.58-7.22 (m, 5H, H(6)benz. and $\mathrm{H}\left(2^{\prime}, 3^{\prime}, 5^{\prime}, 6^{\prime}\right)$ arom.), 4.34 (s superimposed, 2H, $\mathrm{CH}_{2}-\mathrm{Ar}$ ), 4.40-4.18 (m superimposed, 2H, $\mathrm{CH}_{2} \mathrm{CH}_{2}-\mathrm{N}\left(\mathrm{CH}_{3}\right)_{2}$ ), 2.37 (pseudo $\mathrm{s}, 5 \mathrm{H}, 3 \mathrm{H} \mathrm{CH} \mathrm{CH}_{3}=\mathrm{N}-$ and $\left.2 \mathrm{H}, \mathrm{CH}_{2} \mathrm{CH}_{2}-\mathrm{N}\left(\mathrm{CH}_{3}\right)_{2}\right), 2.13(\mathrm{~s}, 6 \mathrm{H}$, $\left.\mathrm{N}\left(\mathrm{CH}_{3}\right)_{2}\right) .{ }^{13} \mathrm{C}-\mathrm{NMR}\left(50 \mathrm{MHz}, \mathrm{DMSO}-d_{6}\right): 178.12,153.82,148.54,142.00,135.72,135.61,131.08,130.87$, 130.42 (2C), 128.01 (2C), 120.91, 117.77, 109.82, 57.71, 45.06 (2C), 41.39, 32.01, 14.00. Anal. calcd. for $\mathrm{C}_{21} \mathrm{H}_{25} \mathrm{ClN}_{6} \mathrm{~S}:$ \% C 58.80, H 5.87, N 19.59, S 7.47; found: \% C 58.68, H 5.57, N 19.82, S 7.11.

2-(1-\{1-[2-(N,N-Dimethylamino)ethyl]-2-(4-ethoxybenzyl)-1H-benzo[d]imidazol-5-yl\}ethylidene)hydrazine-1-carbothioamide (3): Yield: 47\%; m.p. $177-180{ }^{\circ} \mathrm{C} .{ }^{1} \mathrm{H}$ NMR (200 MHz, DMSO-d $d_{6}$ ): 10.18 (s, 1H, NH), 8.23 (s, 1H, NH 2$), 8.11$ (s, 1H, H(4)benz.), 7.96 (s superimposed, $1 \mathrm{H}, \mathrm{NH}_{2}$ ), 7.92 (d superimposed, $J=8.6 \mathrm{~Hz}, 1 \mathrm{H}, \mathrm{H}(7)$ benz.), 7.45 (d, $J=8.6 \mathrm{~Hz}, 1 \mathrm{H}, \mathrm{H}(6)$ benz.), 7.19 (d, $J=7.6 \mathrm{~Hz}, 2 \mathrm{H}, \mathrm{H}\left(3^{\prime}, 5^{\prime}\right)$ arom.), 6.87 (d, $J=8.0 \mathrm{~Hz}, 2 \mathrm{H}, \mathrm{H}\left(2^{\prime}, 6^{\prime}\right)$ arom.), 4.24 (pseudo s, 4H, $\mathrm{CH}_{2}-\mathrm{Ar}$ and $\left.\mathrm{CH}_{2} \mathrm{CH}_{2}-\mathrm{N}\left(\mathrm{CH}_{3}\right)_{2}\right), 3.98\left(\mathrm{~d}, \mathrm{~J}=6.2 \mathrm{~Hz}, 2 \mathrm{H}, \mathrm{OCH}_{2} \mathrm{CH}_{3}\right), 2.37$ (pseudo s, 5H, 3H CH $3 \mathrm{C}=\mathrm{N}-$ and $\left.2 \mathrm{H}, \mathrm{CH}_{2} \mathrm{CH}_{2}-\mathrm{N}\left(\mathrm{CH}_{3}\right)_{2}\right), 2.12\left(\mathrm{~s}, 6 \mathrm{H}, \mathrm{N}\left(\mathrm{CH}_{3}\right)_{2}\right), 1.41-1.18\left(\mathrm{~m}, 3 \mathrm{H}, \mathrm{OCH}_{2} \mathrm{CH}_{3}\right) .{ }^{13} \mathrm{C}-\mathrm{NMR}(50 \mathrm{MHz}$, DMSO- $\left.d_{6}\right): 178.20,156.87,154.44,148.58,141.84,135.79,130.99$ (2C), 129.36 (2C), 128.15, 120.42, 117.02, 114.04 (2C), 109.31, 62.54, 57.46, 45.03 (2C), 41.21, 31.91, 14.25, 14.00. Anal. calcd. for $\mathrm{C}_{23} \mathrm{H}_{30} \mathrm{~N}_{6} \mathrm{OS}: \% \mathrm{C}$ 62.99, H 6.09, N 19.16, S 7.30; found: \% C 63.12, H 6.48, N 19.16, S 7.07. 
2-\{1-[2-(4-Chlorobenzyl)-1-[3-(N,N-dimethylamino)propyl]-1H-benzo[d]imidazol-5-yl]ethylidene\}hydrazine-1-carbothioamide (4): Yield: $45 \%$; m.p. $\quad 110-111{ }^{\circ} \mathrm{C} .{ }^{1} \mathrm{H}$ NMR (200 MHz, DMSO- $d_{6}$ ): $10.18(\mathrm{~s}, 1 \mathrm{H}, \mathrm{NH}), 8.26\left(\mathrm{~s}, 1 \mathrm{H}, \mathrm{NH}_{2}\right), 8.13$ (s, 1H, $\mathrm{H}(4)$ benz.), 7.97 (s superimposed, $1 \mathrm{H}$, $\mathrm{NH}_{2}$ ), 8.10-7.87 (m superimposed, $1 \mathrm{H}, \mathrm{H}(7)$ benz.), 7.47 (d superimposed, $J=8.6 \mathrm{~Hz}, 1 \mathrm{H}, \mathrm{H}(6)$ benz.), 7.37 (pseudo s superimposed, $4 \mathrm{H}, \mathrm{H}\left(2^{\prime}, 3^{\prime}, 5^{\prime}, 6^{\prime}\right)$ arom.), 4.35 (s superimposed, $2 \mathrm{H}, \mathrm{CH}_{2}-\mathrm{Ar}$ ), 4.20 (pseudo s superimposed, $2 \mathrm{H}, \mathrm{CH}_{2} \mathrm{CH}_{2} \mathrm{CH}_{2}-\mathrm{N}\left(\mathrm{CH}_{3}\right)_{2}$ ), 2.37 (pseudo s, $3 \mathrm{H}, \mathrm{CH}_{3} \mathrm{C}=\mathrm{N}-$ ), 2.07 (pseudo s, $8 \mathrm{H}, \mathrm{N}\left(\mathrm{CH}_{3}\right)_{2}$ and $\left.\mathrm{CH}_{2} \mathrm{CH}_{2} \mathrm{CH}_{2}-\mathrm{N}\left(\mathrm{CH}_{3}\right)_{2}\right), 1.69$ (pseudo s, $\left.2 \mathrm{H}, \mathrm{CH}_{2} \mathrm{CH}_{2} \mathrm{CH}_{2}-\mathrm{N}\left(\mathrm{CH}_{3}\right)_{2}\right) .{ }^{13} \mathrm{C}-\mathrm{NMR}$ (50 MHz, DMSO- $\left.d_{6}\right)$ : 178.22, 153.66, 148.54, 141.88, 135.64 (2C), 131.08, 130.90, 130.32 (2C), $128.06(2 \mathrm{C})$, $120.54,117.11,109.33,55.17,44.58(2 \mathrm{C}), 40.74,31.80,26.59,14.00$. Anal. calcd. for $\mathrm{C}_{22} \mathrm{H}_{27} \mathrm{ClN}_{6} \mathrm{~S}: \% \mathrm{C}$ 59,65, H 6.14, N 18.97, S 7.24; found: \% C 59.51, H 6.18, N 19.24, S 7.18.

2-(1-\{1-[2-(N,N-Diethylamino)ethyl]-2-(4-methoxybenzyl)-1H-benzo[d]imidazol-5-yl\}-ethylidene)hydrazine1-carbothioamide (5): Yield: 35\%; m.p. $165-168{ }^{\circ} \mathrm{C} .{ }^{1} \mathrm{H}$ NMR (200 MHz, DMSO-d 6 ): 10.16 (s, 1H, $\mathrm{NH}), 8.25\left(\mathrm{~s}, 1 \mathrm{H}, \mathrm{NH}_{2}\right), 8.10\left(\mathrm{~s}, 1 \mathrm{H}, \mathrm{H}(4)\right.$ benz.), 7.94 (s superimposed, $\left.1 \mathrm{H}, \mathrm{NH}_{2}\right), 8.15-7.85(\mathrm{~m}$ superimposed, $1 \mathrm{H}, \mathrm{H}(7)$ benz.), 7.43 (d superimposed, $J=8.6 \mathrm{~Hz}, 1 \mathrm{H}, \mathrm{H}(6)$ benz.), 7.20 (d, $J=8.2 \mathrm{~Hz}$, $2 \mathrm{H}, \mathrm{H}\left(3^{\prime}, 5^{\prime}\right)$ arom.), 6.89 (d, J = 7.8 Hz, 2H, $\mathrm{H}\left(2^{\prime}, 6^{\prime}\right)$ arom.), 4.26 (s superimposed, $2 \mathrm{H}, \mathrm{CH}_{2}-\mathrm{Ar}$ ), 4.17 (pseudo s superimposed, $\left.2 \mathrm{H}, \mathrm{CH}_{2} \mathrm{CH}_{2}-\mathrm{N}\left(\mathrm{CH}_{2} \mathrm{CH}_{3}\right)_{2}\right), 3.72\left(\mathrm{~s}, 3 \mathrm{H}, \mathrm{OCH}_{3}\right), 2.58-2.24$ (m superimposed

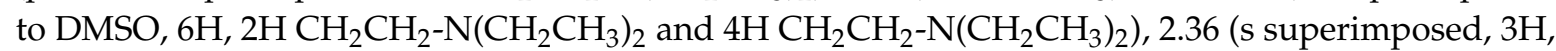
$\left.\mathrm{CH}_{3} \mathrm{C}=\mathrm{N}-\right), 0.78\left(\mathrm{t}, J=6.6 \mathrm{~Hz}, 6 \mathrm{H}, \mathrm{N}-\left(\mathrm{CH}_{2} \mathrm{CH}_{3}\right)_{2}\right) .{ }^{13} \mathrm{C}-\mathrm{NMR}\left(50 \mathrm{MHz}, \mathrm{DMSO}-d_{6}\right): 178.17,157.61$, 154.61, 148.61, 141.81, 135.75, 131.08, 130.87, 129.33 (2C), 128.31, 120.32, 117.01, 113.56 (2C), 109.31, 54.66, 51.33, 46.42 (2C), 41.03, 31.99, 13.95, 11.31 (2C). Anal. calcd. for $\mathrm{C}_{24} \mathrm{H}_{32} \mathrm{~N}_{6} \mathrm{OS}$ : \% C 63.69, H 7.13, N 18.57, S 7.08; found: \% C 63.51, H 6.77, N 18.84, S 7.16.

2-\{1-[2-(4-Chlorobenzyl)-1-[2-(N,N-diethylamino)ethyl]-1H-benzo[d]imidazol-5-yl]-ethylidene\}hydrazine-1carbothioamide (6): Yield: 37\%; m.p. 190-192 ${ }^{\circ} \mathrm{C} .{ }^{1} \mathrm{H}$ NMR (200 MHz, DMSO- $\left.d_{6}\right): 10.18$ (s, 1H, NH), 8.25 (s, $1 \mathrm{H}, \mathrm{NH}_{2}$ ), 8.11 (s, $1 \mathrm{H}, \mathrm{H}(4)$ benz.), 7.96 (s superimposed, $1 \mathrm{H}, \mathrm{NH}_{2}$ ), 8.10-7.85 (m superimposed, $1 \mathrm{H}$, $\mathrm{H}(7)$ benz.), 7.48-7.21 ( $\mathrm{m}, 5 \mathrm{H}, \mathrm{H}(6)$ benz. and $\mathrm{H}\left(2^{\prime}, 3^{\prime}, 5^{\prime}, 6^{\prime}\right)$ arom.), 4.35 (s, 2H, $\left.\mathrm{CH}_{2}-\mathrm{Ar}\right), 4.20$ (pseudo s, $\left.2 \mathrm{H}, \mathrm{CH}_{2} \mathrm{CH}_{2}-\mathrm{N}\left(\mathrm{CH}_{2} \mathrm{CH}_{3}\right)_{2}\right)$, 2.60-2.19 (m superimposed to DMSO, $6 \mathrm{H}, 2 \mathrm{H} \mathrm{CH}_{2} \mathrm{CH}_{2}-\mathrm{N}\left(\mathrm{CH}_{2} \mathrm{CH}_{3}\right)_{2}$ and $\left.4 \mathrm{H} \mathrm{CH}_{2} \mathrm{CH}_{2}-\mathrm{N}\left(\mathrm{CH}_{2} \mathrm{CH}_{3}\right)_{2}\right), 2.36$ (s superimposed, $\left.3 \mathrm{H}, \mathrm{CH}_{3} \mathrm{C}=\mathrm{N}-\right), 0.76\left(\mathrm{t}, J=6.6 \mathrm{~Hz}, 6 \mathrm{H}, \mathrm{N}\left(\mathrm{CH}_{2} \mathrm{CH}_{3}\right)_{2}\right)$. ${ }^{13} \mathrm{C}-\mathrm{NMR}\left(50 \mathrm{MHz}\right.$, DMSO- $\left.d_{6}\right): 178.13,153.94,148.59,141.92,135.64(2 \mathrm{C}), 131.12(2 \mathrm{C}), 130.38(2 \mathrm{C})$, 128.03 (2C), 120.29, 117.09, 109.52, 51.93, 46.43 (2C), 41.08, 32.03, 14.01, 11.31 (2C). Anal. calcd. for $\mathrm{C}_{23} \mathrm{H}_{29} \mathrm{ClN}_{6} \mathrm{~S}:$ \% C 60.44, H 6.40, N 18.39, S 7.01; found: \% C 60.57, H 6.45, N 18.52, S 7.10.

2-(1-\{1-[2-(N,N-Diethylamino)ethyl]-2-(4-ethoxybenzyl)-1H-benzo[d]imidazol-5-yl\}-ethylidene)hydrazine-1carbothioamide (7): Yield: 47\%; m.p. $189-192.5^{\circ} \mathrm{C} .{ }^{1} \mathrm{H}$ NMR (200 MHz, DMSO-d6): 10.18 (s, 1H, NH), $8.24\left(\mathrm{~s}, 1 \mathrm{H}, \mathrm{NH}_{2}\right), 8.10\left(\mathrm{~s}, 1 \mathrm{H}, \mathrm{H}(4)\right.$ benz.), 7.94 (s superimposed, $\left.1 \mathrm{H}, \mathrm{NH}_{2}\right), 8.05-7.85$ (m superimposed, 1H, H(7)benz.), 7.42 (d, $J=8.6 \mathrm{~Hz}, 1 \mathrm{H}, \mathrm{H}(6)$ benz.), 7.19 (d, $J=8.4 \mathrm{~Hz}, 2 \mathrm{H}, \mathrm{H}\left(3^{\prime}, 5^{\prime}\right)$ arom.), 6.87 (d, $J=$ $8.4 \mathrm{~Hz}, 2 \mathrm{H}, \mathrm{H}\left(2^{\prime}, 6^{\prime}\right)$ arom.), 4.27 (s superimposed, $2 \mathrm{H}, \mathrm{CH}_{2}-\mathrm{Ar}$ ), 4.18 (pseudo s superimposed, $2 \mathrm{H}$, $\left.\mathrm{CH}_{2} \mathrm{CH}_{2}-\mathrm{N}\left(\mathrm{CH}_{2} \mathrm{CH}_{3}\right)_{2}\right), 3.98\left(\mathrm{q}, \mathrm{J}=7 \mathrm{~Hz}, 2 \mathrm{H}, \mathrm{OCH}_{2} \mathrm{CH}_{3}\right), 2.60-2.23$ (m superimposed to DMSO, $6 \mathrm{H}$, $2 \mathrm{H} \mathrm{CH}_{2} \mathrm{CH}_{2}-\mathrm{N}\left(\mathrm{CH}_{2} \mathrm{CH}_{3}\right)_{2}$ and $\left.4 \mathrm{H} \mathrm{CH}_{2} \mathrm{CH}_{2}-\mathrm{N}\left(\mathrm{CH}_{2} \mathrm{CH}_{3}\right)_{2}\right), 2.37$ (s superimposed, $3 \mathrm{H}, \mathrm{CH}_{3} \mathrm{C}=\mathrm{N}-$ ), 1.30 $\left(\mathrm{t}, J=6.8 \mathrm{~Hz}, 3 \mathrm{H}, \mathrm{OCH}_{2} \mathrm{CH}_{3}\right), 0.78\left(\mathrm{t}, J=6.6 \mathrm{~Hz}, 6 \mathrm{H}, \mathrm{N}\left(\mathrm{CH}_{2} \mathrm{CH}_{3}\right)_{2}\right) .{ }^{13} \mathrm{C}-\mathrm{NMR}\left(50 \mathrm{MHz}, \mathrm{DMSO}-d_{6}\right)$ : $178.20,156.87,154.60,148.60,141.85,135.75,130.89,129.32$ (2C), 128.19, 120.32, 117.03, 114.06 (2C), 109.31, 62.55, 51.46, 46.41 (2C), 41.06, 32.01, 14.25, 13.97, 11.32 (2C). Anal. calcd. for $\mathrm{C}_{25} \mathrm{H}_{34} \mathrm{~N}_{6} \mathrm{OS}: \% \mathrm{C}$ 64.35, H 7.34, N 18.01, S 6.87; found: \% C 64.30, H 7.51, N 18.10, S 6.77.

2-(1-\{2-Benzyl-1-[3-(N,N-diethylamino)propyl]-1H-benzo[d]imidazol-5-yl\}ethylidene)-hydrazine-1carbothioamide (8): Yield: 38\%; m.p. $168-169{ }^{\circ} \mathrm{C} .{ }^{1} \mathrm{H}$ NMR (200 MHz, DMSO-d6): 10.19 (s, $1 \mathrm{H}, \mathrm{NH}), 8.27\left(\mathrm{~s}, 1 \mathrm{H}, \mathrm{NH}_{2}\right), 8.14\left(\mathrm{~s}, 1 \mathrm{H}, \mathrm{H}(4)\right.$ benz.), 7.97 (s superimposed, $\left.1 \mathrm{H}, \mathrm{NH}_{2}\right), 8.03-7.87(\mathrm{~m}$ superimposed, $1 \mathrm{H}, \mathrm{H}(7)$ benz.), $7.47\left(\mathrm{~d}, J=8.2 \mathrm{~Hz}, 1 \mathrm{H}, \mathrm{H}(6)\right.$ benz.), 7.31 (s, $5 \mathrm{H}, \mathrm{H}\left(2^{\prime}, 3^{\prime}, 4^{\prime}, 5^{\prime}, 6^{\prime}\right)$ arom.), 4.34 (s, 2H, $\mathrm{CH}_{2}-\mathrm{Ar}$ ), 4.19 (pseudo s, $\left.2 \mathrm{H}, \mathrm{CH}_{2} \mathrm{CH}_{2} \mathrm{CH}_{2}-\mathrm{N}_{(}\left(\mathrm{CH}_{2} \mathrm{CH}_{3}\right)_{2}\right), 2.37$ (s, 3H, $\mathrm{CH}_{3} \mathrm{C}=\mathrm{N}-$ ), 2.45-2.19 (m, 9H, $4 \mathrm{H} \mathrm{N}\left(\mathrm{CH}_{2} \mathrm{CH}_{3}\right)_{2}, 2 \mathrm{H} \mathrm{CH}_{2} \mathrm{CH}_{2} \mathrm{CH}_{2}-\mathrm{N}\left(\mathrm{CH}_{2} \mathrm{CH}_{3}\right)_{2}$ and $3 \mathrm{H} \mathrm{CH}{ }_{3} \mathrm{C}=\mathrm{N}-$ ), 1.63 (pseudo $\mathrm{s}, 2 \mathrm{H}$, $\left.\mathrm{CH}_{2} \mathrm{CH}_{2} \mathrm{CH}_{2}-\mathrm{N}\left(\mathrm{CH}_{2} \mathrm{CH}_{3}\right)_{2}\right), 0.90$ (pseudo s, 6H, N( $\left.\left.\mathrm{CH}_{2} \mathrm{CH}_{3}\right)_{2}\right) .{ }^{13} \mathrm{C}-\mathrm{NMR}$ (50 MHz, DMSO-d 6 ): 178.20, 
$153.90,148.58,141.93,136.59,135.60,131.02,128.25$ (2C), 128.16 (2C), 126.23, 120.45, 117.11, 109.31, 48.66, 45.56 (2C), 41.03, 32.65, 26.16, 14.01, 11.05 (2C). Anal. calcd. for $\mathrm{C}_{24} \mathrm{H}_{32} \mathrm{~N}_{6} \mathrm{~S}: \%$ C 66.02, $\mathrm{H} 7.39, \mathrm{~N}$ 19.25, S 7.34; found \% C 65.84, H 7.53, N 19.37, S 7.58.

2-(1-\{1-[3-(N,N-Diethylamino)propyl]-2-(4-methoxybenzyl)-1H-benzo[d]imidazol-5-yl\}ethylidene)hydrazine-1carbothioamide (9): Yield: 38\%; m.p. 180.7-182.9 ${ }^{\circ} \mathrm{C} .{ }^{1} \mathrm{H}$ NMR (200 MHz, DMSO-d 6 ): 10.18 (s, 1H, NH), 8.24 (s, 1H, $\mathrm{NH}_{2}$ ), 8.12 (s, 1H, H(4)benz.), 7.95 (s superimposed, 1H, $\mathrm{NH}_{2}$ ), 8.03-7.85 (m superimposed, 1H, H(7)benz.), 7.45 (d, $J=8.6 \mathrm{~Hz}, 1 \mathrm{H}, \mathrm{H}(6)$ benz.), 7.21 (d, J = 8.4 Hz, 2H, H(3' ,5')arom.), 6.88 (d, $J=8.2 \mathrm{~Hz}, 2 \mathrm{H}, \mathrm{H}\left(2^{\prime}, 6^{\prime}\right.$ )arom.), 4.26 (s superimposed, $2 \mathrm{H}, \mathrm{CH}_{2}-\mathrm{Ar}$ ), 4.16 (pseudo s superimposed, $\left.2 \mathrm{H}, \mathrm{CH}_{2} \mathrm{CH}_{2} \mathrm{CH}_{2}-\mathrm{N}\left(\mathrm{CH}_{2} \mathrm{CH}_{3}\right)_{2}\right), 3.71\left(\mathrm{~s}, 3 \mathrm{H}, \mathrm{OCH}_{3}\right), 2.37\left(\mathrm{~s}, 3 \mathrm{H}, \mathrm{CH}_{3} \mathrm{C}=\mathrm{N}-\right), 2.42-2.17(\mathrm{~m}, 6 \mathrm{H}, 4 \mathrm{H}$ $\mathrm{N}\left(\mathrm{CH}_{2} \mathrm{CH}_{3}\right)_{2}$ and $2 \mathrm{H} \mathrm{CH}_{2} \mathrm{CH}_{2} \mathrm{CH}_{2}-\mathrm{N}\left(\mathrm{CH}_{2} \mathrm{CH}_{3}\right)_{2}$ ), 1.61 (pseudo s, $2 \mathrm{H}, \mathrm{CH}_{2} \mathrm{CH}_{2} \mathrm{CH}_{2}-\mathrm{N}_{(}\left(\mathrm{CH}_{2} \mathrm{CH}_{3}\right)_{2}$ ), $0.89\left(\mathrm{t}, J=6.8 \mathrm{~Hz}, 6 \mathrm{H}, \mathrm{N}\left(\mathrm{CH}_{2} \mathrm{CH}_{3}\right)_{2}\right) .{ }^{13} \mathrm{C}-\mathrm{NMR}\left(50 \mathrm{MHz}, \mathrm{DMSO}-d_{6}\right): 178.20,157.62,154.23,148.60$, $141.92,135.63,130.97,129.23$ (2C), 128.34, 120.40, 117.07, 113.55 (2C), 109.26, 54.62, 48.75, 45.56 (2C), $41.04,31.84,26.23,14.00,11.16$ (2C). Anal. calcd. for $\mathrm{C}_{25} \mathrm{H}_{34} \mathrm{~N}_{6} \mathrm{OS}$ : \% C 64.35, H 7.34, N 18.01, S 6.87; found \% C 64.19, H 7.74, N 17.96, S 6.85.

2-(1-\{2-[(2H-Benzo[d][1,2,3]triazol-2-yl)methyl]-1-[2-(N,N-dimethylamino)ethyl]-1H-benzo[d]imidazol-5yl\}ethylidene)hydrazine-1-carbothioamide (18): Yield: 46\%; m.p. 214-217 ${ }^{\circ} \mathrm{C} .{ }^{1} \mathrm{H}$ NMR $(200 \mathrm{MHz}$, DMSO- $d_{6}$ ): 10.19 (s, 1H, NH), 8.26 (s, 1H, NH ), 8.14 (s, 1H, H(4)benz.), 8.07-7.85 (m, 4H, 1H $\mathrm{H}(7)$ benz., $1 \mathrm{H} \mathrm{NH} 2$ and $2 \mathrm{H} \mathrm{H}\left(4^{\prime}, 7^{\prime}\right)$ bzt.), 7.55 (d, J = 8.6 Hz, 1H, H(6)benz.), $7.52-7.39$ (m, 2H, $\mathrm{H}\left(5^{\prime}, 6^{\prime}\right)$ bzt.), 6.44 (s, 2H, $\mathrm{CH}_{2}-\mathrm{Ar}$ ), 4.44 (pseudo s, $\left.\left.2 \mathrm{H}, \mathrm{CH}_{2} \mathrm{CH}_{2}-\mathrm{N}_{(} \mathrm{CH}_{3}\right)_{2}\right), 2.43-2.29$ (m superimposed, $\left.2 \mathrm{H}, \mathrm{CH}_{2} \mathrm{CH}_{2}-\mathrm{N}\left(\mathrm{CH}_{3}\right)_{2}\right), 2.36\left(\mathrm{~s}, 3 \mathrm{H}, \mathrm{CH}_{3} \mathrm{C}=\mathrm{N}-\right), 2.14\left(\mathrm{~s}, 6 \mathrm{H}, \mathrm{N}\left(\mathrm{CH}_{3}\right)_{2}\right) .{ }^{13} \mathrm{C}-\mathrm{NMR}\left(50 \mathrm{MHz}, \mathrm{DMSO}-d_{6}\right)$ : 178.24, 148.60, 148.23, 143.58 (2C), 141.49, 135.68, 131.65, 126.43 (2C), 121.45, 117.74, 117.54 (2C), 109.91, 57.79, 52.31, 45.08 (2C), 41.84, 13.96. Anal. calcd. for $\mathrm{C}_{21} \mathrm{H}_{25} \mathrm{~N}_{9} \mathrm{~S}$ : \% C 57.91, H 5.79, N 28.94, S 7.36; found \% C 57.90, H 5.90, N 28.64, S 7.22.

2-(1-\{2-[(2H-Benzo[d][1,2,3]triazol-2-yl)methyl]-1-[3-(N,N-dimethylamino)propyl]-1H-benzo[d]imidazol-5yl\}ethylidene)hydrazine-1-carbothioamide (19): Yield: 31\%; m.p. 212-214 ${ }^{\circ} \mathrm{C} .{ }^{1} \mathrm{H}$ NMR $(200 \mathrm{MHz}$, DMSO- $d_{6}$ ): 10.19 (s, 1H, NH), 8.26 (s, 1H, -NH2), 8.14 (s, 1H, H(4)benz.), 8.06-7.80 (m, 4H, 1H $\mathrm{H}(7)$ benz., $1 \mathrm{H} \mathrm{NH}_{2}$ and $2 \mathrm{H} \mathrm{H}\left(4^{\prime}, 7^{\prime}\right)$ bzt.), 7.68-7.50 (m, 1H, H(6)benz.), 7.47 (pseudo s superimposed, $2 \mathrm{H}, \mathrm{H}\left(5^{\prime}, 6^{\prime}\right)$ bzt.) 6.47 (s, 2H, $\mathrm{CH}_{2}$-Ar), 4.39 (pseudo s, $\left.2 \mathrm{H}, \mathrm{CH}_{2} \mathrm{CH}_{2} \mathrm{CH}_{2}-\mathrm{N}\left(\mathrm{CH}_{3}\right)_{2}\right), 2.36$ (s, 3H, $\mathrm{CH}_{3} \mathrm{C}=\mathrm{N}-$ ), 2.21-1.90 (m superimposed, $2 \mathrm{H}, \mathrm{CH}_{2} \mathrm{CH}_{2} \mathrm{CH}_{2}-\mathrm{N}\left(\mathrm{CH}_{3}\right)_{2}$ ), 2.05 (s superimposed, 6H, $\left.\mathrm{N}\left(\mathrm{CH}_{3}\right)_{2}\right), 1.73$ (pseudo s, $\left.2 \mathrm{H}, \mathrm{CH}_{2} \mathrm{CH}_{2} \mathrm{CH}_{2}-\mathrm{N}\left(\mathrm{CH}_{3}\right)_{2}\right) .{ }^{13} \mathrm{C}-\mathrm{NMR}\left(50 \mathrm{MHz}, \mathrm{DMSO}-d_{6}\right): 178.25,148.38$, 148.25, 143.56 (2C), 141.61, 135.48, 131.66, 126.40 (2C), 121.47, 117.77, 117.53 (2C), 109.94, 54.86, 52.01, 44.41 (2C), 41.11, 26.30, 13.96. Anal. calcd. for $\mathrm{C}_{22} \mathrm{H}_{27} \mathrm{~N}_{9} \mathrm{~S}$ : \% C 58.77, H 6.05, N 28.04, S 7.13; found \% C 58.88, H 5.96, N 27.78, S 7.33.

2-(1-\{2-[(2H-Benzo[d][1,2,3]triazol-2-yl)methyl]-1-[3-(N,N-diethylamino)propyl]-1H-benzo[d]imidazol-5yl\}ethylidene)hydrazine-1-carbothioamide (21): Yield: 78\%; m.p. $214-216{ }^{\circ} \mathrm{C} .{ }^{1} \mathrm{H}$ NMR $(200 \mathrm{MHz}$, DMSO- $d_{6}$ ): 10.18 (s, 1H, NH), 8.27 (s, 1H, NH ${ }_{2}$ ), 8.13 (s, 1H, H(4)benz.), 8.09-7.86 (m, 4H, 1H H(7)benz., $1 \mathrm{H} \mathrm{NH}_{2}$ and $2 \mathrm{H} \mathrm{H}\left(4^{\prime}, 7^{\prime}\right)$ bzt. $), 7.55$ (d, $J=8.8 \mathrm{~Hz}, 1 \mathrm{H}, \mathrm{H}(6)$ benz.), 7.53-7.39 (m, 2H, H( $\left.5^{\prime}, 6^{\prime}\right)$ bzt. $), 6.47$ (s, 2H, $\mathrm{CH}_{2}-\mathrm{Ar}$ ), 4.40 (pseudo s, $2 \mathrm{H}, \mathrm{CH}_{2} \mathrm{CH}_{2}-\mathrm{N}\left(\mathrm{CH}_{2} \mathrm{CH}_{3}\right)_{2}$ ), 2.67-2.25 (m superimposed to DMSO, $6 \mathrm{H}, 2 \mathrm{H} \mathrm{CH}_{2} \mathrm{CH}_{2}-\mathrm{N}\left(\mathrm{CH}_{2} \mathrm{CH}_{3}\right)_{2}$ and $\left.4 \mathrm{H} \mathrm{N}\left(\mathrm{CH}_{2} \mathrm{CH}_{3}\right)_{2}\right), 2.36\left(\mathrm{~s}, 3 \mathrm{H}, \mathrm{CH}_{3} \mathrm{C}=\mathrm{N}-\right), 0.77(\mathrm{t}, J=6.8 \mathrm{~Hz}, 6 \mathrm{H}$, $\left.\mathrm{N}\left(\mathrm{CH}_{2} \mathrm{CH}_{3}\right)_{2}\right) .{ }^{13} \mathrm{C}-\mathrm{NMR}\left(50 \mathrm{MHz}, \mathrm{DMSO}-d_{6}\right): 178.25,148.82,148.25,143.59$ (2C), 141.52, 135.58, 131.54, 126.40 (2C), 121.34, 117.74, 117.54 (2C), 109.88, 52.43, 51.68, 46.55 (2C), 42.29, 13.91, 11.26 (2C). Anal. calcd. for $\mathrm{C}_{23} \mathrm{H}_{29} \mathrm{~N}_{9}$ S: \% C 59.59, H 6.31, N 27.19, S 6.92; found \% C 59.61, H 6.54, N 27.06, S 7.15.

2-(1-\{2-[(2H-Benzo[d][1,2,3]triazol-1-yl)methyl]-1-[3-(N,N-dimethylamino)propyl]-1H-benzo[d]imidazol5-yl\}ethylidene)hydrazine-1-carbothioamide (22): Yield: 34\%; m.p. 201-203 ${ }^{\circ} \mathrm{C} .{ }^{1} \mathrm{H} \mathrm{NMR}(200 \mathrm{MHz}$, DMSO- $\left.d_{6}\right): 10.17(\mathrm{~s}, 1 \mathrm{H}, \mathrm{NH}), 8.23\left(\mathrm{~s}, 1 \mathrm{H}, \mathrm{NH}_{2}\right), 8.12$ (s superimposed, 1H, H(4)benz.), 8.18-8.05 (m, $1 \mathrm{H}, \mathrm{H}\left(7^{\prime}\right)$ bzt. $),\left(\mathrm{s}, 1 \mathrm{H}, \mathrm{NH}_{2}\right), 8.02-7.93\left(\mathrm{~m}, 2 \mathrm{H}, 1 \mathrm{H} \mathrm{H}\left(4^{\prime}\right)\right.$ bzt. and $\left.1 \mathrm{H} \mathrm{NH}_{2}\right), 7.89(\mathrm{~d}, J=8.6 \mathrm{~Hz}, 1 \mathrm{H}$

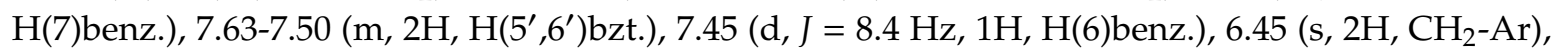
4.42 (pseudo s, $2 \mathrm{H}, \mathrm{CH}_{2} \mathrm{CH}_{2} \mathrm{CH}_{2}-\mathrm{N}\left(\mathrm{CH}_{3}\right)_{2}$ ), 2.33 (s, 3H, $\mathrm{CH}_{3} \mathrm{C}=\mathrm{N}-$ ), 2.35-1.90 (m superimposed, 2H, 
$\left.\mathrm{CH}_{2} \mathrm{CH}_{2} \mathrm{CH}_{2}-\mathrm{N}\left(\mathrm{CH}_{3}\right)_{2}\right), 2.13$ (s, 6H, N( $\left.\left.\mathrm{CH}_{3}\right)_{2}\right), 1.79$ (pseudo s, $\left.2 \mathrm{H}, \mathrm{CH}_{2} \mathrm{CH}_{2} \mathrm{CH}_{2}-\mathrm{N}\left(\mathrm{CH}_{3}\right)_{2}\right) .{ }^{13} \mathrm{C}-\mathrm{NMR}$ (50 MHz, DMSO- $d_{6}$ ): 178.21, 148.98, 148.25, 144.91, 141.50, 135.61, 132.87, 131.58, 127.23, 123.80, 121.39, $118.85,117.62,110.61,109.89,54.86,44.43(2 \mathrm{C}), 44.03,41.02,26.27,13.90$. Anal. calcd. for $\mathrm{C}_{22} \mathrm{H}_{27} \mathrm{~N}_{9} \mathrm{~S}: \%$ C 58.77, H 6.05, N 28.04, S 7.13; found \% C 58.92, H 6.18, N 28.06, S 6.84.

\subsubsection{General Procedure for the Preparation of Semicarbazones}

To a solution of the proper 5-acetyl benzimidazole $(0.80 \mathrm{mmol})$ in ethanol $(2 \mathrm{~mL})$, a solution of semicarbazide hydrochloride $(2.4 \mathrm{mmol})$ previously dissolved in $8 \mathrm{~mL}$ of a $1 \mathrm{~N}$ solution of sodium acetate was added. The mixture was refluxed for $4 \mathrm{~h}$ under stirring. After evaporation of the solvent, the oily residue was treated with warm water to get rid of the remaining semicarbazide. The crude was purified by $\mathrm{CC}\left(\mathrm{SiO}_{2}, \mathrm{CH}_{2} \mathrm{Cl}_{2}+5 \% \mathrm{DEA}\right)$, obtaining the title compound as a white solid.

2-(1-\{1-[2-(N,N-Dimethylamino)ethyl]-2-(4-methoxybenzyl)-1H-benzo[d]imidazol-5-yl\}ethylidene)hydrazine-1-carboxamide (10): Yield: 69\%; m.p. 203-205 ${ }^{\circ} \mathrm{C} .{ }^{1} \mathrm{H}$ NMR $(200 \mathrm{MHz}$, DMSO- $\left.d_{6}\right): 9.28(\mathrm{~s}, 1 \mathrm{H}, \mathrm{NH}), 7.98$ (s, $1 \mathrm{H}, \mathrm{H}(4)$ benz.), $7.83(\mathrm{~d}, J=8.8 \mathrm{~Hz}, 1 \mathrm{H}, \mathrm{H}(7)$ benz.), 7.43 (d, $J=8.6$ $\mathrm{Hz}, 1 \mathrm{H}, \mathrm{H}(6)$ benz.), 7.21 (d, $J=8.6 \mathrm{~Hz}, 2 \mathrm{H}, \mathrm{H}\left(3^{\prime}, 5^{\prime}\right)$ arom.), 6.89 (d, J = 8.6 Hz, $2 \mathrm{H}, \mathrm{H}\left(2^{\prime}, 6^{\prime}\right)$ arom.), 6.50 (broad s, $2 \mathrm{H}, \mathrm{NH}_{2}$ ), 4.24 (s superimposed, $2 \mathrm{H}, \mathrm{CH}_{2}-\mathrm{Ar}$ ), $4.39-4.17\left(\mathrm{~m}, 2 \mathrm{H}, \mathrm{CH}_{2} \mathrm{CH}_{2}-\mathrm{N}\left(\mathrm{CH}_{3}\right)_{2}\right), 3.72$ (s, $3 \mathrm{H}, \mathrm{OCH}_{3}$ ), 2.41-2.20 (m superimposed, $\left.2 \mathrm{H}, \mathrm{CH}_{2} \mathrm{CH}_{2}-\mathrm{N}\left(\mathrm{CH}_{3}\right)_{2}\right)$, 2.25 (s superimposed, $3 \mathrm{H}, \mathrm{CH}_{3} \mathrm{C}=\mathrm{N}-$ ), 2.12 (s superimposed, $\left.6 \mathrm{H}, \mathrm{N}\left(\mathrm{CH}_{3}\right)_{2}\right) .{ }^{13} \mathrm{C}-\mathrm{NMR}\left(50 \mathrm{MHz}, \mathrm{DMSO}-d_{6}\right): 157.63,157.09,154.20,144.64$, 141.86, 135.23, 131.78, 129.37 (2C), 128.34, 119.88, 116.18, 113.56 (2C), 109.25, 57.45, 54.67, 45.04 (2C), 41.12, 31.91, 13.38. Anal. calcd. for $\mathrm{C}_{22} \mathrm{H}_{28} \mathrm{~N}_{6} \mathrm{O}_{2}$ : \% C 64.68, H 6.91, N 20.57; found \% C 64.70, H 6.67, N 20.35.

2-\{1-[2-(4-Chlorobenzyl)-1-[2-(N,N-dimethylamino)ethyl]-1H-benzo[d]imidazol-5-yl\}-ethylidene)hydrazine1-carboxamide (11): Yield: 59\%; m.p. 217-220 ${ }^{\circ} \mathrm{C} .{ }^{1} \mathrm{H}$ NMR $\left(200 \mathrm{MHz}, \mathrm{DMSO}-d_{6}\right): 9.29(\mathrm{~s}, 1 \mathrm{H}$, $\mathrm{NH}), 7.99$ (s, 1H, H(4)benz.), 7.83 (d, $J=8.2 \mathrm{~Hz}, 1 \mathrm{H}, \mathrm{H}(7)$ benz.), 7.48-7.24 (m, 5H, H(7)benz. and $\mathrm{H}\left(2^{\prime}, 3^{\prime}, 5^{\prime}, 6^{\prime}\right.$ )arom.), 6.52 (broad $\mathrm{s}, 2 \mathrm{H}, \mathrm{NH}_{2}$ ), 4.33 (s superimposed, $2 \mathrm{H}, \mathrm{CH}_{2}-\mathrm{Ar}$ ), 4.41-4.17 (m superimposed, $\left.2 \mathrm{H}, \mathrm{CH}_{2} \mathrm{CH}_{2}-\mathrm{N}\left(\mathrm{CH}_{3}\right)_{2}\right), 3.72\left(\mathrm{~s}, 3 \mathrm{H}, \mathrm{OCH}_{3}\right), 2.42-2.30\left(\mathrm{~m}, 2 \mathrm{H}, \mathrm{CH}_{2} \mathrm{CH}_{2}-\mathrm{N}\left(\mathrm{CH}_{3}\right)_{2}\right), 2.26$ $\left(\mathrm{s}, 3 \mathrm{H}, \mathrm{CH}_{3} \mathrm{C}=\mathrm{N}-\right), 2.13\left(\mathrm{~s}, 6 \mathrm{H}, \mathrm{N}\left(\mathrm{CH}_{3}\right)_{2}\right) .{ }^{13} \mathrm{C}-\mathrm{NMR}\left(50 \mathrm{MHz}, \mathrm{DMSO}-d_{6}\right)$ : 157.11, 153.57, 144.64, 141.83, 135.66, 135.16, 131.88, 130.87, 130.39 (2C), 128.03 (2C), 120.01, 116.23, 109.34, 57.57, 45.05 (2C), 41.18, 31.92, 13.37. Anal. calcd. for $\mathrm{C}_{21} \mathrm{H}_{25} \mathrm{ClN}_{6} \mathrm{O}$ : \% C 61.08, H 6.10, N 20.35; found \% C 61.08, H 5.95, N 20.65 .

2-(1-\{1-[2-(N,N-Dimethylamino)ethyl]-2-(4-ethoxybenzyl)-1H-benzo[d]imidazol-5-yl\}-ethylidene)hydrazine1-carboxamide (12): Yield: 38\%; m.p. $210-213{ }^{\circ} \mathrm{C} .{ }^{1} \mathrm{H}$ NMR (200 MHz, DMSO- $d_{6}$ ): 9.28 (s, 1H, NH), 7.99 (s, 1H, H(4)benz.), 7.83 (d, J = 8.6 Hz, 1H, H(7)benz.), 7.43 (d, J = 8.6 Hz, 1H, H(6)benz.), 7.19 (d, J = 7.4 $\mathrm{Hz}, 2 \mathrm{H}, \mathrm{H}\left(3^{\prime}, 5^{\prime}\right)$ arom.), 6.87 (d, J = 7.6 Hz, 2H, H(2',6')arom.), 6.50 (broad s, 2H, $\mathrm{NH}_{2}$ ), 4.24 (pseudo s, $4 \mathrm{H}, \mathrm{CH}_{2}-\mathrm{Ar}$ and $\left.\mathrm{CH}_{2} \mathrm{CH}_{2}-\mathrm{N}\left(\mathrm{CH}_{3}\right)_{2}\right), 3.98\left(\mathrm{q}, J=6.8 \mathrm{~Hz}, 2 \mathrm{H}, \mathrm{OCH}_{2} \mathrm{CH}_{3}\right), 2.41-2.18$ (m superimposed, $\left.2 \mathrm{H}, \mathrm{CH}_{2} \mathrm{CH}_{2}-\mathrm{N}\left(\mathrm{CH}_{3}\right)_{2}\right), 2.25$ (s superimposed, $\left.3 \mathrm{H}, \mathrm{CH}_{3} \mathrm{C}=\mathrm{N}-\right), 2.12\left(\mathrm{~s}, 6 \mathrm{H}, \mathrm{N}\left(\mathrm{CH}_{3}\right)_{2}\right), 1.30(\mathrm{t}, J=6.8 \mathrm{~Hz}$, $\left.3 \mathrm{H}, \mathrm{OCH}_{2} \mathrm{CH}_{3}\right) .{ }^{13} \mathrm{C}-\mathrm{NMR}\left(50 \mathrm{MHz}\right.$, DMSO- $\left.d_{6}\right): 157.09,156.87,154.20,144.64,141.87,135.23,131.79$, 129.34 (2C), 128.21, 119.88, 116.19, 114.06 (2C), 109.25, 62.56, 57.44, 45.03 (2C), 41.13, 31.92, 14.25, 13.38 . Anal. calcd. for $\mathrm{C}_{23} \mathrm{H}_{30} \mathrm{~N}_{6} \mathrm{O}_{2}$ : \% C 65.38, H 7.16, N 19.89; found \% C 65.56, H 7.48, N 19.70.

2-\{1-[2-(4-Chlorobenzyl)-1-[3-(N,N-dimethylamino)propyl]-1H-benzo[d]imidazol-5-yl\}-ethylidene)hydrazine1-carboxamide (13): Yield: 67\%; m.p. $211-212.5{ }^{\circ} \mathrm{C} .{ }^{1} \mathrm{H}$ NMR $\left(200 \mathrm{MHz}, \mathrm{DMSO}-d_{6}\right): 9.29(\mathrm{~s}, 1 \mathrm{H}$, $\mathrm{NH}), 8.00$ (s, 1H, H(4)benz.), 7.83 (d, $J=8.2 \mathrm{~Hz}, 1 \mathrm{H}, \mathrm{H}(7)$ benz.), 7.47-7.20 (m, 5H, H(6)benz. and $\mathrm{H}\left(2^{\prime}, 3^{\prime}, 5^{\prime}, 6^{\prime}\right)$ arom.), 6.51 (broad $\left.\mathrm{s}, 2 \mathrm{H}, \mathrm{NH}_{2}\right), 4.34\left(\mathrm{~s}, 2 \mathrm{H}, \mathrm{CH}_{2}-\mathrm{Ar}\right), 4.26-4.13(\mathrm{~m}, 2 \mathrm{H}$, $\left.\mathrm{CH}_{2} \mathrm{CH}_{2} \mathrm{CH}_{2}-\mathrm{N}\left(\mathrm{CH}_{3}\right)_{2}\right), 2.26\left(\mathrm{~s}, 3 \mathrm{H}, \mathrm{CH}_{3} \mathrm{C}=\mathrm{N}-\right), 2.20-1.98\left(\mathrm{~m}, 8 \mathrm{H}, 2 \mathrm{H} \mathrm{CH}_{2} \mathrm{CH}_{2} \mathrm{CH}_{2}-\mathrm{N}\left(\mathrm{CH}_{3}\right)_{2}\right.$ and $6 \mathrm{H}$ $\left.\mathrm{N}\left(\mathrm{CH}_{3}\right)_{2}\right), 1.81-1.58\left(\mathrm{~m}, 2 \mathrm{H}, \mathrm{CH}_{2} \mathrm{CH}_{2} \mathrm{CH}_{2}-\mathrm{N}\left(\mathrm{CH}_{3}\right)_{2} .{ }^{13} \mathrm{C}-\mathrm{NMR}\left(50 \mathrm{MHz}, \mathrm{DMSO}-d_{6}\right): 157.08,153.40\right.$, 144.58, 141.90, 135.69, 135.07, 131.87, 130.89, 130.29 (2C), 128.06 (2C), 119.98, 116.27, 109.28, 55.17, 44.58 (2C), 40.71, 31.80, 26.59, 13.37. Anal. calcd. for $\mathrm{C}_{22} \mathrm{H}_{27} \mathrm{ClN}_{6} \mathrm{O}: \%$ C 61.89, $\mathrm{H} 6.37, \mathrm{~N} 19.68$; found \% C $62.09, \mathrm{H} 6.63, \mathrm{~N} 19.89$. 
2-(1-\{1-[2-(N,N-Diethylamino)ethyl]-2-(4-methoxybenzyl)-1H-benzo[d]imidazol-5-yl\}-ethylidene)hydrazine1-carboxamide (14): Yield: 72\%; m.p. $207-209^{\circ} \mathrm{C} .{ }^{1} \mathrm{H}$ NMR (200 MHz, DMSO- $\left.d_{6}\right)$ : 9.26 (s, $\left.1 \mathrm{H}, \mathrm{NH}\right), 7.98$ (s, 1H, H(4)benz.), 7.84 (d, J = 8.6 Hz, 1H, H(7)benz.), 7.41 (d, J = $8.6 \mathrm{~Hz}, 1 \mathrm{H}, \mathrm{H}(6)$ benz.), 7.20 (d, J = 8.8 $\mathrm{Hz}, 2 \mathrm{H}, \mathrm{H}\left(3^{\prime}, 5^{\prime}\right)$ arom.), 6.89 (d, $J=8.8 \mathrm{~Hz}, 2 \mathrm{H}, \mathrm{H}\left(2^{\prime}, 6^{\prime}\right)$ arom.), 6.49 (broad s, $\left.2 \mathrm{H}, \mathrm{NH}_{2}\right), 4.27$ (s, 2H, $\left.\mathrm{CH}_{2}-\mathrm{Ar}\right), 4.22-4.09\left(\mathrm{~m}, 2 \mathrm{H}, \mathrm{CH}_{2} \mathrm{CH}_{2}-\mathrm{N}\left(\mathrm{CH}_{2} \mathrm{CH}_{3}\right)_{2}\right), 3.72\left(\mathrm{~s}, 3 \mathrm{H}, \mathrm{OCH}_{3}\right), 2.50-2.36$ (m superimposed to DMSO, $6 \mathrm{H}, 2 \mathrm{H} \mathrm{CH}_{2} \mathrm{CH}_{2}-\mathrm{N}\left(\mathrm{CH}_{2} \mathrm{CH}_{3}\right)_{2}$ and $\left.4 \mathrm{H} \mathrm{CH}_{2} \mathrm{CH}_{2}-\mathrm{N}\left(\mathrm{CH}_{2} \mathrm{CH}_{3}\right)_{2}\right), 2.26\left(\mathrm{~s}, 3 \mathrm{H}, \mathrm{CH}_{3} \mathrm{C}=\mathrm{N}-\right), 0.78$ (t, $\left.J=7.0 \mathrm{~Hz}, 6 \mathrm{H}, \mathrm{N}\left(\mathrm{CH}_{2} \mathrm{CH}_{3}\right)_{2}\right) .{ }^{13} \mathrm{C}-\mathrm{NMR}\left(50 \mathrm{MHz}, \mathrm{DMSO}-d_{6}\right): 157.63,157.09,154.36,144.67,141.88$, 135.20, 131.68, 129.30 (2C), 128.40, 119.76, 116.19, 113.57 (2C), 109.21, 54.66, 51.39, 46.45 (2C), 41.13, $32.02,13.34,11.39$ (2C). Anal. calcd. for $\mathrm{C}_{24} \mathrm{H}_{32} \mathrm{~N}_{6} \mathrm{O}_{2}$ : \% C 66.03, H 7.39, N 19.25; found \% C 65.98, H 7.42, N 19.56.

2-\{1-[2-(4-Chlorobenzyl)-1-[2-(N,N-diethylamino)ethyl]-1H-benzo[d]imidazol-5-yl\}-ethylidene)hydrazine1-carboxamide (15): Yield: 56\%; m.p. $196.5-198.5{ }^{\circ} \mathrm{C} .{ }^{1} \mathrm{H}$ NMR (200 MHz, DMSO-d6): 9.27 (s, 1H, NH), 7.97 (s, 1H, H(4)benz.), 7.85 (d, $J=8.6 \mathrm{~Hz}, 1 \mathrm{H}, \mathrm{H}(7)$ benz.), 7.51-7.24 (m, 5H, H(6)benz. and $\mathrm{H}\left(2^{\prime}, 3^{\prime}, 5^{\prime}, 6^{\prime}\right)$ arom.), 6.50 (broad $\left.\mathrm{s}, 1 \mathrm{H}, \mathrm{NH}_{2}\right), 4.34\left(\mathrm{~s}, 2 \mathrm{H}, \mathrm{CH}_{2}-\mathrm{Ar}\right), 4.19$ (pseudo $\mathrm{s}, 2 \mathrm{H}$, $\left.\mathrm{CH}_{2} \mathrm{CH}_{2}-\mathrm{N}\left(\mathrm{CH}_{2} \mathrm{CH}_{3}\right)_{2}\right)$, 2.58-2.33 (m superimposed to DMSO, $6 \mathrm{H}, 2 \mathrm{H} \mathrm{CH}_{2} \mathrm{CH}_{2}-\mathrm{N}_{(}\left(\mathrm{CH}_{2} \mathrm{CH}_{3}\right)_{2}$ and $4 \mathrm{H}$ $\left.\mathrm{CH}_{2} \mathrm{CH}_{2}-\mathrm{N}\left(\mathrm{CH}_{2} \mathrm{CH}_{3}\right)_{2}\right), 2.25$ (s superimposed, $\left.3 \mathrm{H}, \mathrm{CH}_{3} \mathrm{C}=\mathrm{N}-\right), 0.76\left(\mathrm{t}, J=6.4 \mathrm{~Hz}, 6 \mathrm{H}, \mathrm{N}\left(\mathrm{CH}_{2} \mathrm{CH}_{3}\right)_{2}\right)$. ${ }^{13} \mathrm{C}-\mathrm{NMR}\left(50 \mathrm{MHz}\right.$, DMSO- $d_{6}$ ): 157.09, 153.73, 144.62, 141.81, 135.68, 135.12, 131.74, 130.87, 130.34 (2C), 128.03 (2C), 119.88, 116.23, 109.32, 51.41, 46.43 (2C), 42.10, 32.04, 13.32, 11.23 (2C). Anal. calcd. for $\mathrm{C}_{23} \mathrm{H}_{29} \mathrm{ClN}_{6} \mathrm{O}: \%$ C 62.65, H 6.63, N 19.06; found: \% C 62.58, H 6.50, N 19.26.

2-(1-\{1-[3-(N,N-Diethylamino)propyl]-2-benzyl-1H-benzo[d]imidazol-5-yl\}ethylidene)-hydrazine1-carboxamide (16): Yield: 32\%; m.p. $185-189{ }^{\circ} \mathrm{C} .{ }^{1} \mathrm{H}$ NMR (200 MHz, DMSO-d6): 9.28 (s, $1 \mathrm{H}, \mathrm{NH}), 8.01$ (s, 1H, H(4)benz.), 7.82 (d, $J=8.6 \mathrm{~Hz}, 1 \mathrm{H}, \mathrm{H}(7)$ benz.), 7.45 (d, J = 8.6 Hz, 1H, H(6)benz.), 7.30 (pseudo s, $5 \mathrm{H}, \mathrm{H}\left(2^{\prime}, 3^{\prime}, 5^{\prime}, 6^{\prime}\right)$ arom.), 6.50 (broad s, $\left.1 \mathrm{H}, \mathrm{NH}_{2}\right), 4.33\left(\mathrm{~s}, 2 \mathrm{H}, \mathrm{CH}_{2}-\mathrm{Ar}\right.$ ), 4.17 (pseudo $\left.\mathrm{s}, 2 \mathrm{H}, \mathrm{CH}_{2} \mathrm{CH}_{2} \mathrm{CH}_{2}-\mathrm{N}\left(\mathrm{CH}_{2} \mathrm{CH}_{3}\right)_{2}\right), 2.47-2.27$ (m superimposed, $6 \mathrm{H}, 2 \mathrm{H} \mathrm{CH}_{2} \mathrm{CH}_{2} \mathrm{CH}_{2}-\mathrm{N}\left(\mathrm{CH}_{2} \mathrm{CH}_{3}\right)_{2}$ and $4 \mathrm{H} \mathrm{CH}_{2} \mathrm{CH}_{2}-\mathrm{N}\left(\mathrm{CH}_{2} \mathrm{CH}_{3}\right)_{2}$ ), 2.26 (s superimposed, $3 \mathrm{H}, \mathrm{CH}_{3} \mathrm{C}=\mathrm{N}-$ ), 1.62 (pseudo $\mathrm{s}, 2 \mathrm{H}$, $\left.\mathrm{CH}_{2} \mathrm{CH}_{2} \mathrm{CH}_{2}-\mathrm{N}\left(\mathrm{CH}_{2} \mathrm{CH}_{3}\right)_{2}\right), 0.90$ (pseudo s, 6H, $\left.\mathrm{N}\left(\mathrm{CH}_{2} \mathrm{CH}_{3}\right)_{2}\right) .{ }^{13} \mathrm{C}-\mathrm{NMR}\left(50 \mathrm{MHz}, \mathrm{DMSO}-d_{6}\right): 157.07$, 153.64, 144.62, 141.95, 136.65, 135.04, 131.80, 128.22 (2C), 128.15 (2C), 126.20, 119.89, 116.26, 109.25, $48.69,45.56$ (2C), 41.10, 32.65, 26.17, 13.36, 11.06 (2C). Anal. calcd. for $\mathrm{C}_{24} \mathrm{H}_{32} \mathrm{~N}_{6} \mathrm{O}: \%$ C 68.54, $\mathrm{H}$ 7.67, N 19.98; found: \% C 68.35, H 7.84, N 20.30.

2-(1-\{1-[3-(N,N-Diethylamino)propyl]-2-(4-methoxybenzyl)-1H-benzo[d]imidazol-5-yl\}-ethylidene)hydrazine1-carboxamide (17): Yield: $32 \%$; m.p. $190-192{ }^{\circ} \mathrm{C} .{ }^{1} \mathrm{H}$ NMR (200 MHz, DMSO- $\left.d_{6}\right): 9.28$ (s, $\left.1 \mathrm{H}, \mathrm{NH}\right), 7.99$ (s, 1H, H(4)benz.), 7.83 (d, J = 8.6 Hz, 1H, H(7)benz.), 7.44 (d, J = 8.6 Hz, 1H, H(6)benz.), 7.21 (d, J = 7.0 $\mathrm{Hz}, 2 \mathrm{H}, \mathrm{H}\left(3^{\prime}, 5^{\prime}\right)$ arom.), 6.88 (d, J = 7.2 Hz, 2H, H(2', $\left.6^{\prime}\right)$ arom.), 6.51 (broad s, $\left.2 \mathrm{H}, \mathrm{NH}_{2}\right), 4.25$ (s, 2H, $\mathrm{CH}_{2}-\mathrm{Ar}$ ), 4.22-4.07 (m superimposed, $\left.2 \mathrm{H}, \mathrm{CH}_{2} \mathrm{CH}_{2} \mathrm{CH}_{2}-\mathrm{N}\left(\mathrm{CH}_{2} \mathrm{CH}_{3}\right)_{2}\right), 3.71\left(\mathrm{~s}, 3 \mathrm{H}, \mathrm{OCH}_{3}\right), 2.46-2.20$ (m superimposed, $6 \mathrm{H}, 2 \mathrm{H} \mathrm{CH}{ }_{2} \mathrm{CH}_{2} \mathrm{CH}_{2}-\mathrm{N}\left(\mathrm{CH}_{2} \mathrm{CH}_{3}\right)_{2}$ and $\left.4 \mathrm{H} \mathrm{N}\left(\mathrm{CH}_{2} \mathrm{CH}_{3}\right)_{2}\right), 2.26\left(\mathrm{~s}, 3 \mathrm{H}, \mathrm{CH}_{3} \mathrm{C}=\mathrm{N}-\right.$ ), 1.60 (pseudo s, $\left.2 \mathrm{H}, \mathrm{CH}_{2} \mathrm{CH}_{2} \mathrm{CH}_{2}-\mathrm{N}\left(\mathrm{CH}_{2} \mathrm{CH}_{3}\right)_{2}\right), 0.89$ (pseudo s, $6 \mathrm{H}, \mathrm{N}\left(\mathrm{CH}_{2} \mathrm{CH}_{3}\right)_{2}$ ). ${ }^{13} \mathrm{C}-\mathrm{NMR}$ (50 MHz, DMSO- $d_{6}$ ): 157.61, 157.07, 153.98, 144.62, 141.95, 135.07, 131.75, 129.22 (2C), 128.40, 119.84, 116.23, 113.55 (2C), 109.20, 54.61, 48.76, 45.56 (2C), 41.29, 31.85, 26.24, 13.37, 11.15 (2C). Anal. calcd. for $\mathrm{C}_{25} \mathrm{H}_{34} \mathrm{~N}_{6} \mathrm{O}_{2}$ : \% C 66.64, H 7.61, N 18.65; found \% C 66.38, H 7.56, N 18.31 .

2-(1-\{2-[(2H-Benzo[d][1,2,3]triazol-2-yl)methyl]-1-[2-(N,N-dimethylamino)ethyl]-1H-benzo[d]imidazol5-yllethylidene)hydrazine-1-carboxamide (20): Yield: 48\%; m.p. $209-212{ }^{\circ} \mathrm{C} .{ }^{1} \mathrm{H}$ NMR $(200 \mathrm{MHz}$, DMSO- $\left.d_{6}\right)$ : $9.31(\mathrm{~s}, 1 \mathrm{H}, \mathrm{NH}), 8.03(\mathrm{~s}, 1 \mathrm{H}, \mathrm{H}(4)$ benz.), $8.00-7.85(\mathrm{~m}, 3 \mathrm{H}, 1 \mathrm{H} \mathrm{H}(7)$ benz., and $2 \mathrm{H}$ $\mathrm{H}\left(4^{\prime}, 7^{\prime}\right)$ bzt.), 7.59-7.41 (m, 3H, $1 \mathrm{H} \mathrm{H}(6)$ benz. and $2 \mathrm{H} \mathrm{H}\left(5^{\prime}, 6^{\prime}\right)$ bzt.), 6.53 (broad s, $\left.2 \mathrm{H}, \mathrm{NH}_{2}\right), 6.43$ (s, $\left.2 \mathrm{H}, \mathrm{CH}_{2}-\mathrm{Ar}\right), 4.53-4.34\left(\mathrm{~m}, 2 \mathrm{H}, \mathrm{CH}_{2} \mathrm{CH}_{2}-\mathrm{N}\left(\mathrm{CH}_{3}\right)_{2}\right), 2.46-2.34\left(\mathrm{~m}, 2 \mathrm{H}, \mathrm{CH}_{2} \mathrm{CH}_{2}-\mathrm{N}\left(\mathrm{CH}_{3}\right)_{2}\right), 2.24(\mathrm{~s}, 3 \mathrm{H}$, $\left.\mathrm{CH}_{3} \mathrm{C}=\mathrm{N}-\right), 2.14\left(\mathrm{~s}, 6 \mathrm{H}, \mathrm{N}\left(\mathrm{CH}_{3}\right)_{2}\right) .{ }^{13} \mathrm{C}-\mathrm{NMR}\left(50 \mathrm{MHz}, \mathrm{DMSO}-d_{6}\right): 157.03,148.32,144.29,143.57(2 \mathrm{C})$, 141.52, 135.14, 132.42, 126.42 (2C), 120.95, 117.74, 117.54 (2C), 116.85, 109.85, 57.77, 52.30, 45.08 (2C), 41.56, 13.31. Anal. calcd. for $\mathrm{C}_{21} \mathrm{H}_{25} \mathrm{~N}_{9} \mathrm{O}: \%$ C 60.13, H 6.01, N 30.05; found \% C 60.39, H 6.35, N 30.80. 


\subsubsection{General Procedure for the Preparation of Hydrazones}

A solution of $\mathrm{NH}_{2} \mathrm{NH}_{2} \cdot \mathrm{H}_{2} \mathrm{O}(2.5 \mathrm{mmol})$ in $3 \mathrm{~mL}$ of water was refluxed for $5 \mathrm{~h}$ with a solution of the proper 5-acetyl benzimidazole $(0.50 \mathrm{mmol})$ in $2.5 \mathrm{~mL}$ of ethanol with stirring. At room temperature, $5 \mathrm{~mL}$ of water were added and the solution was kept at $0-5{ }^{\circ} \mathrm{C}$ overnight. The expected product was directly separated from the solution as an amorphous solid that was filtered and crystallized as a white solid from anhydrous $\mathrm{Et}_{2} \mathrm{O}$.

1-[2-(N,N-Dimethylamino)ethyl]-2-(4-methoxybenzyl)-5-(1-hydrazineylideneethyl)-1H-benzo[d]imidazole (23): Yield: 53\%; m.p. $175.5-176.5^{\circ} \mathrm{C} .{ }^{1} \mathrm{H}$ NMR (200 MHz, DMSO-d6): 8.11 (s, 1H, H(4)benz.), 7.92 (pseudo s, 1H, H(7)benz.), 7.55 (pseudo s, 1H, H(6)benz.), 7.22 (pseudo s, 2H, H(3' ,5')arom.), 6.91 (pseudo s, 2H, $\mathrm{H}\left(2^{\prime}, 6^{\prime}\right)$ arom.), 6.27 (broad s, $\left.2 \mathrm{H}, \mathrm{NH}_{2}\right), 4.39-4.10\left(\mathrm{~m}, 4 \mathrm{H}, \mathrm{CH}_{2}-\mathrm{Ar}\right.$ and $\left.\mathrm{CH}_{2} \mathrm{CH}_{2}-\mathrm{N}\left(\mathrm{CH}_{3}\right)_{2}\right), 3.73(\mathrm{~s}, 3 \mathrm{H}$, $\mathrm{OCH}_{3}$ ), 2.61-2.28 (m superimposed to DMSO, 5H, $2 \mathrm{H} \mathrm{CH}_{2} \mathrm{CH}_{2}-\mathrm{N}\left(\mathrm{CH}_{3}\right)_{2}$ and $\left.3 \mathrm{H} \mathrm{CH}{ }_{3} \mathrm{C}=\mathrm{N}-\right), 2.14$ (s, $\left.6 \mathrm{H}, \mathrm{N}\left(\mathrm{CH}_{3}\right)_{2}\right) .{ }^{13} \mathrm{C}-\mathrm{NMR}\left(50 \mathrm{MHz}, \mathrm{DMSO}-d_{6}\right)$ : 158.17, 157.66, 154.57, 141.84, 136.09, 131.58, $129.36(2 \mathrm{C})$, $128.28,120.17,116.89,113.60$ (2C), 109.53, 57.42, 54.67, 45.05 (2C), 41.13, 31.93, 14.53. Anal. calcd. for $\mathrm{C}_{21} \mathrm{H}_{27} \mathrm{~N}_{5} \mathrm{O}$ : \% C 69.01, H 7.45, N 19.16; found \% C 69.20, H 7.35, N 19.16.

1-[2-(N,N-diethylamino)ethyl]-2-(4-ethoxybenzyl)-5-(1-hydrazineylideneethyl)-1H-benzo[d]imidazole (24): Yield: 44\%; m.p. $80-82{ }^{\circ} \mathrm{C} .{ }^{1} \mathrm{H}$ NMR (200 MHz, DMSO-d6): 8.11 (s, 1H, H(4)benz.), 7.87 (d, J $=8.6 \mathrm{~Hz}, 1 \mathrm{H}, \mathrm{H}(7)$ benz.), 7.47 (d, $J=8.6 \mathrm{~Hz}, 1 \mathrm{H}, \mathrm{H}(6)$ benz.), 7.21 (pseudo s, 2H, H( $\left.3^{\prime}, 5^{\prime}\right)$ arom.), 6.89 (pseudo s, 2H, H(2',6')arom.), 6.32 (broad s, 2H, $\left.\mathrm{NH}_{2}\right), 4.41-4.13(\mathrm{~m}, 4 \mathrm{H}, 2 \mathrm{H} \mathrm{CH}-\mathrm{Ar}$ and $2 \mathrm{H}$ $\mathrm{CH}_{2} \mathrm{CH}_{2}-\mathrm{N}\left(\mathrm{CH}_{2} \mathrm{CH}_{3}\right)_{2}$ ), 3.97 (pseudo s, 2H, $\mathrm{OCH}_{2} \mathrm{CH}_{3}$ ), 2.58-2.27 (m superimposed to DMSO, 6H, $2 \mathrm{H} \mathrm{CH}_{2} \mathrm{CH}_{2}-\mathrm{N}\left(\mathrm{CH}_{2} \mathrm{CH}_{3}\right)_{2}$ and $\left.4 \mathrm{H} \mathrm{N}\left(\mathrm{CH}_{2} \mathrm{CH}_{3}\right)_{2}\right), 2.29$ (s superimposed, $\left.3 \mathrm{H}, \mathrm{CH}_{3} \mathrm{C}=\mathrm{N}-\right), 1.31(\mathrm{t}, J=$ $\left.6.8 \mathrm{~Hz}, 3 \mathrm{H}, \mathrm{OCH}_{2} \mathrm{CH}_{3}\right), 0.78\left(\mathrm{t}, J=6.8 \mathrm{~Hz}, 6 \mathrm{H}, \mathrm{N}\left(\mathrm{CH}_{2} \mathrm{CH}_{3}\right)_{2}\right) .{ }^{13} \mathrm{C}-\mathrm{NMR}\left(50 \mathrm{MHz}, \mathrm{DMSO}-d_{6}\right): 158.18$, 157.64, 154.24, 141.87, 135.89, 131.67, 129.23 (2C), 128.34, 120.04, 116.89, 113.78 (2C), 109.57, 62.67, 57.43, 45.09 (2C), 41.12, 31.91, 14.44, 13.98, 11.23 (2C). Anal. calcd. for $\mathrm{C}_{24} \mathrm{H}_{33} \mathrm{~N}_{5} \mathrm{O}$ : \% C 70.73, H 8.16, N 17.18; found \% C 70.67, H 8.47, N 17.43 .

2-[(Benzotriazol-2-yl)methyl]-1-[2-(N,N-diethylamino)ethyl]-5-(1-hydrazineylideneethyl)-1H-benzo[d]imidazole (25): Yield: 35\%; m.p. $128-130{ }^{\circ} \mathrm{C} .{ }^{1} \mathrm{H}$ NMR (200 MHz, DMSO-d6): 8.01-7.87 (m, 2H, H( $4^{\prime}$, $\left.7^{\prime}\right)$ bzt.), 7.76 (s, $1 \mathrm{H}, \mathrm{H}(4)$ benz.), 7.70 (d, $J=8.8 \mathrm{~Hz}, 1 \mathrm{H}, \mathrm{H}(7)$ benz.), $7.60-7.38\left(\mathrm{~m}, 3 \mathrm{H}, 1 \mathrm{H} \mathrm{H}(6)\right.$ benz. and $2 \mathrm{H} \mathrm{H}\left(5^{\prime}, 6^{\prime}\right) \mathrm{bzt}$ ), 6.43 (s, 2H, CH $2-A r), 6.26$ (broad s, 2H, NH$)_{2}$, 4.43-4.21 (m, 2H, $\left.\mathrm{CH}_{2} \mathrm{CH}_{2}-\mathrm{N}\left(\mathrm{CH}_{2} \mathrm{CH}_{3}\right)_{2}\right), 2.64-2.48(\mathrm{~m}$ superimposed to DMSO, $\left.2 \mathrm{H}, \mathrm{CH}_{2} \mathrm{CH}_{2}-\mathrm{N}\left(\mathrm{CH}_{2} \mathrm{CH}_{3}\right)_{2}\right), 2.42$ (q, J = 6.8 Hz, 4H, N( $\left.\left.\mathrm{CH}_{2} \mathrm{CH}_{3}\right)_{2}\right), 2.08$ (s, $\left.3 \mathrm{H}, \mathrm{CH}_{3} \mathrm{C}=\mathrm{N}-\right), 1.31\left(\mathrm{t}, \mathrm{J}=6.8 \mathrm{~Hz}, 3 \mathrm{H}, \mathrm{OCH}_{2} \mathrm{CH}_{3}\right), 0.76\left(\mathrm{t}, J=6.8 \mathrm{~Hz}, 6 \mathrm{H}, \mathrm{N}\left(\mathrm{CH}_{2} \mathrm{CH}_{3}\right)_{2}\right) .{ }^{13} \mathrm{C}-\mathrm{NMR}(50$ MHz, DMSO-d $)_{6}$ : 158.04, 148.86, 147.97, 143.57, 141.42, 135.84, 134.07, 132.11, 126.49 (2C), 121.15, 117.51 (2C), 110.16, 52.31, 51.61, 46.49 (2C), 42.59, 14.52, 11.15 (2C). Anal. calcd. for $\mathrm{C}_{22} \mathrm{H}_{28} \mathrm{~N}_{8}$ : \% C 65.32, $\mathrm{H}$ 6.98, N 27.70; found \% C 65.57, H 6.69, N 27.58.

\subsection{Biology}

Antiviral Assays

The detailed antiviral procedures can be found elsewhere [24-27]. Briefly, human influenza viruses A/HK/7/87 (A/H3N2), A/Ned/378/05 (A/H1N1) and B/Ned/537/05 (all from R. Fouchier, Rotterdam, the Netherlands) were tested in Madin-Darby canine kidney (MDCK) cells, a kind gift from M. Matrosovich (Marburg, Germany). Respiratory syncytial virus (RSV; strain Long) was evaluated on human epithelial type 2 cells (Hep-2), and human coronavirus 229E was assessed on human embryonic lung (HEL) fibroblast cells (all from ATCC). For the other viruses, we refer to our previous report [25]. Semiconfluent cultures of MDCK, Hep-2, Vero or HEL cells in 96-well plates were infected with viruses at a multiplicity of infection of $100 \mathrm{CCID}_{50}(50 \%$ cell culture infective dose). At the same time, serial compound dilutions were added. The plates were incubated (at $35^{\circ} \mathrm{C}$ for influenza and coronavirus, and at $37^{\circ} \mathrm{C}$ for the other viruses) for 4 to 6 days, until full-blown cytopathic effect (CPE) was visible. At that time, microscopy was performed to score the viral CPE and compound cytotoxicity (assessed in mock-infected plates). Next, the MTS cell viability reagent (CellTiter 96 ${ }^{\circledR}$ AQueous One Solution 
Cell Proliferation Assay from Promega) was added, and after $3 \mathrm{~h}$ of incubation at $37^{\circ} \mathrm{C}$, the $\mathrm{OD}_{490 \mathrm{~nm}}$ values were measured in a plate reader. The compounds' $\mathrm{EC}_{50}(50 \%$ antivirally effective concentration) values were calculated by interpolation using semi-log dose response curves. For the MTS data, the percentage of protection against virus was defined as: $\left(\left(\mathrm{OD}_{\mathrm{Cpd}}\right)\right.$ virus $-\left(\mathrm{OD}_{\mathrm{Contr}}\right)$ virus $\left.)\right) /\left(\left(\mathrm{OD}_{\mathrm{Contr}}\right) \mathrm{mock}_{\mathrm{C}}\right.$ $-\left(\mathrm{OD}_{\mathrm{Contr}}\right)$ virus $) \times 100$, where $\left(\mathrm{OD}_{\mathrm{Cpd}}\right)$ virus is the $\mathrm{OD}$ for a given concentration of the compound in virus-infected cells; $\left(\mathrm{OD}_{\text {Contr }}\right)$ virus is the $\mathrm{OD}$ for the untreated virus control; and $\left(\mathrm{OD}_{\text {Contr }}\right)$ mock is the $\mathrm{OD}$ for the untreated mock-infected control. The values for $\mathrm{CC}_{50}$ (50\% cytotoxic concentration) were also calculated by interpolation using semi-log dose response curves. The percentage of cytotoxicity was defined as: $\left(1-\left(\mathrm{OD}_{\mathrm{Cpd}}\right)\right.$ mock $/\left(\left(\mathrm{OD}_{\mathrm{Contr}}\right)\right.$ mock $) \times 100$, where $\left(\mathrm{OD}_{\mathrm{Cpd}}\right)$ mock is the OD for a given concentration of the compound in mock-infected wells.

\subsection{Molecular Modelling Studies}

\subsubsection{Docking Calculations}

All the compounds were built, parameterized (Gasteiger-Huckel method) and energy minimized within MOE using MMFF94 forcefield [34]. All ligands were used in their protonated state. Docking calculations within the X-ray structure of RSV F protein (pdb code $=5 \mathrm{KWW}$ ) were done using the LeadIT 2.1.8 software suite (www.biosolveit.com) including the FlexX scoring algorithm, which is based on binding free energy calculations by means of Gibbs-Helmholtz equation [35-37]. The software detects the binding site defining a radius of $10 \AA$ far from the co-crystallized ligand, in order to set up a spherical search space for the docking approach. The standard settings for the docking strategy were followed, choosing the so-called hybrid approach (enthalpy and entropy criteria); the related scoring function evaluation is described in the literature [38]. The derived docking poses were prioritized by the score values of the lowest energy pose of the compounds docked to the protein structure. All ligands were refined and rescored by assessment with the algorithm HYDE, included in the LeadIT 2.1.8 software. The HYDE module considers dehydration enthalpy and hydrogen bonding [39,40]. Finally, the reliability of the selected docking poses was assessed using a short $\sim 1$ ps run of molecular dynamics (MD) at constant temperature, followed by an all-atom energy minimization (LowModeMD implemented in MOE software). This represents a conformational search method that uses implicit vibrational analysis to focus a MD trajectory along the low-mode vibrations [41-43]. This has the effect of searching for minima along the valleys and troughs on the potential energy surface, thereby performing an exhaustive conformational analysis of the ligand-receptor binding site complex, as we previously discussed about other case studies [44-46].

\subsubsection{In Silico Evaluation of Pharmacokinetic Properties}

ADME properties have been predicted by means of Advanced Chemistry Development (ACD) Percepta platform (www.acdlabs.com) named ACD/Labs Percepta software (version 2.0). All of the calculated parameters were derived and evaluated by Percepta on the basis of training libraries, implemented in the software, which include a consistent number of molecules, whose pharmacokinetic and toxicity profiles are known.

\section{Conclusions}

In summary, this study reports the synthesis of a series of (thio)semicarbazone- and hydrazone-containing benzimidazoles for the development of novel antiviral agents which have shown the ability to inhibit the replication of three human respiratory viruses. Acute viral respiratory illnesses are usually the result of infections with a heterogeneous group of respiratory viruses, including some of the most notable RNA viruses, such as influenza virus, coronavirus and RSV. The relative infections continue to cause frequent morbidity, and sometimes cause severe outcomes, including about 3.9 million deaths worldwide each year, particularly among children under five years, the elderly and immunocompromised individuals $[47,48]$. This scenario enlightens the serious and important 
need for identifying new scaffolds that are useful in discovering innovative, highly potent and safe antiviral agents [7].

Interestingly, our antiviral data suggest compounds 6, 8, 16 and 17 work as dual virus inhibitors of influenza and coronavirus strains. In these series the (thio)semicarbazone and hydrazone moieties have proven to mediate the observed antiviral activity of 2-benzylbenzimidazoles and 2-[(benzotriazol-1/2-yl)methyl]benzimidazole scaffolds, since the respective chemical precursor 5 -acetylbenzimidazoles were found to be less effective or ineffective antiviral agents. It is worth noting that, although the efficacy against human coronavirus (229E) is moderate, these compounds are the first benzimidazole derivatives to be found as active against this virus. Their chemical optimization might acquire greater importance in light of the current outbreak of the novel coronavirus (2019-nCoV); WHO is calling for the urgent setting up of a complex network of strategies, which also look for accelerating the development of diagnostics, vaccines and therapeutics to contain the pandemic proportion of 2019-nCoV infections [49].

Moreover, compounds $\mathbf{2 5}$ and $\mathbf{2 2}$ proved to be the most potent and safe antivirals among these series, being able to inhibit RSV replication with the same degree of potency of ribavirin, $\mathrm{w}$ is the only drug available to treat RSV infections, but its limited efficacy and low margin of safety restrict its use to children at high risk [50]. Docking studies also performed on the best performing RSV F protein inhibitors reported in the literature supported the SAR observed in these series of compounds, and enlightened the efficient binding modes of $\mathbf{2 5}$ and $\mathbf{2 2}$ at the exposed surface of the RSV F protein, establishing $\pi-\pi$ stacking and cation- $\pi$ interactions with the hydrophobic pocket formed by F137, F140 and $\mathrm{F} 488$ residues.

Therefore, the above adequately substituted (thio)semicarbazone- and hydrazone-based benzimidazoles, inhibiting the replication of the aforementioned viruses, may be considered as promising new hits, worthy of further structural optimization for an improved antiviral profile, as a result of the chemical variation of the benzimidazole core: (a) by exploring different side chains in position 1 and/or (b) replacing the benzyl or (benzotriazolyl)methyl moieties with different aromatic or heteroaromatic rings. In particular, with the aim of obtaining more effective and drug-like anti-RSV agents, the design process will be driven by the previously built CoMFA and CoMSIA models, filtering tools predicting the safety trend of any new analogue prior to synthesis [19]. Meanwhile, as some compounds are able to target both influenza virus and coronavirus, their underlying possible common mechanisms of viral inhibition are worth investigation.

Supplementary Materials: The following are available online, Figure S1, Docking positioning of the RSV F protein inhibitor 25 and of the inactive analogue 21, Figure S2, Docking positioning of the RSV F protein of the inactive analogues 19 and 21, Figure S3, Docking positioning of the RSV F protein inhibitor 22 and of the inactive analogue 4 .

Author Contributions: Conceptualization, M.T.; methodology, M.T. and L.N.; software, E.C.; validation, V.F., M.T., S.S. and L.N.; formal analysis, V.F., S.S., L.N. and M.T.; investigation, V.F., E.C. and L.N.; resources, E.C., S.S., L.N. and M.T. data curation, M.T. and L.N.; writing-original draft preparation, M.T.; writing-review and editing, M.T., L.N., S.S. and E.C.; visualization, S.S. and M.T.; supervision, L.N. and M.T.; project administration, M.T. and L.N. All authors have read and agreed to the published version of the manuscript.

Funding: This research received no external funding.

Conflicts of Interest: The authors declare no conflict of interest.

\section{References and Note}

1. Tahlan, S.; Kumar, S.; Narasimhan, B. Pharmacological significance of heterocyclic 1H-benzimidazole scaffolds: A review. BMC Chem. 2019, 13, 101. [CrossRef] [PubMed]

2. Ajani, O.O.; Aderohunmu, D.V.; Ikpo, C.O.; Adedapo, A.E.; Olanrewaju, I.O. Functionalized Benzimidazole Scaffolds: Privileged Heterocycle for Drug Design in Therapeutic Medicine. Arch. Pharm. Chem. Life Sci. 2016, 349, 475-506. [CrossRef] [PubMed] 
3. Akhtar, W.; Khan, M.F.; Verma, G.; Shaquiquzzaman, M.; Rizvi, M.A.; Mehdi, S.H.; Akhter, M.; Alam, M.M. Therapeutic evolution of benzimidazole derivatives in the last quinquennial period. Eur. J. Med. Chem. 2017, 126, 705-753. [CrossRef] [PubMed]

4. Keri, R.S.; Hiremathad, A.; Budagumpi, S.; Nagaraja, B.M. Comprehensive review in current developments of benzimidazole-based medicinal chemistry. Chem. Biol. Drug Des. 2015, 86, 19-65. [CrossRef] [PubMed]

5. Kharitonova, M.I.; Konstantinova, I.D.; Miroshnikov, A.I. Benzimidazole nucleosides: Antiviral and antitumour activities, methods of synthesis. Russ. Chem. Rev. 2018, 87, 1111-1138. [CrossRef]

6. Heylen, E.; Neyts, J.; Jochmans, D. Drug candidates and model systems in respiratory syncytial virus antiviral drug discovery. Biochem. Pharmacol. 2017, 127, 1-12. [CrossRef]

7. Behzadi, M.A.; Leyva-Grado, V.H. Overview of current therapeutics and novel candidates against influenza, respiratory syncytial virus, and middle east respiratory syndrome coronavirus infections. Front. Microbiol. 2019, 10, 1327. [CrossRef]

8. Vausselin, T.; Séron, K.; Lavie, M.; Mesalam, A.A.; Lemasson, M.; Belouzard, S.; Fénéant, L.; Danneels, A.; Rouillé, Y.; Cocquerel, L.; et al. Identification of a new benzimidazole derivative as an antiviral against Hepatitis C virus. J. Virol. 2016, 90, 8422-8434.

9. Scarim, C.B.; Jornada, D.H.; Machado, M.G.M.; Ferreira, C.M.R.; Dos Santos, J.L.; Chung, M.C. Thiazole, thio and semicarbazone derivatives against tropical infective diseases: Chagas disease, human African trypanosomiasis (HAT), leishmaniasis, and malaria. Eur. J. Med. Chem. 2019, 162, 378-395. [CrossRef]

10. Beteck, R.M.; Seldon, R.; Jordaan, A.; Warner, D.F.; Hoppe, H.C.; Laming, D.; Khanye, S.D. New quinolone-based thiosemicarbazones showing activity against Plasmodium falciparum and Mycobacterium tuberculosis. Molecules 2019, 24, E1740. [CrossRef]

11. Kune, G.A. To-day's drugs: Methisazone. Br. Med. J. 1964, 2, 621. [PubMed]

12. Rogolino, D.; Bacchi, A.; De Luca, L.; Rispoli, G.; Sechi, M.; Stevaert, A.; Naesens, L.; Carcelli, M. Investigation of the salicylaldehyde thiosemicarbazone scaffold for inhibition of influenza virus PA endonuclease. J. Biol. Inorg. Chem. 2015, 20, 1109-1121. [CrossRef] [PubMed]

13. Vitale, G.; Corona, P.; Loriga, M.; Carta, A.; Paglietti, G.; Giliberti, G.; Sanna, G.; Farci, P.; Marongiu, M.E.; La Colla, P. 5-Acetyl-2-arylbenzimidazoles as antiviral agents. Part 4. Eur. J. Med. Chem. 2012, 53, 83-97. [CrossRef] [PubMed]

14. Soraires Santacruz, M.C.; Fabiani, M.; Castro, E.F.; Cavallaro, L.V.; Finkielsztein, L.M. 2Synthesis, antiviral evaluation and molecular docking studies of N4-aryl substituted/unsubstituted thiosemicarbazones derived from 1-indanones as potent anti-bovine viral diarrhea virus agents. Bioorg. Med. Chem. 2017, 25, 4055-4063. [CrossRef] [PubMed]

15. Tonelli, M.; Tasso, B.; Mina, L.; Paglietti, G.; Boido, V.; Sparatore, F. Primary anti-proliferative activity evaluation of 1-(quinolizidin-1'-yl)methyl- and 1-( $\omega$-tert-amino)alkyl-substituted 2-phenyl-, 2-benzyl- and 2-[(benzotriazol-1/2-yl)methyl]benzimidazoles on human cancer cell lines. Mol. Divers. 2013, 17, 409-419. [CrossRef]

16. Tonelli, M.; Cichero, E.; Mokhtar, A.; Rabbito, A.; Tasso, B.; Fossa, P.; Ligresti, A. Exploring the effectiveness of novel benzimidazoles as CB2 ligands: Synthesis, biological evaluation, molecular docking studies and ADMET prediction. Med. Chem. Commun. 2018, 9, 2045-2054. [CrossRef]

17. Tonelli, M.; Simone, M.; Tasso, B.; Novelli, F.; Boido, V.; Sparatore, F.; Paglietti, G.; Pricl, S.; Giliberti, G.; Blois, S.; et al. Antiviral activity of Benzimidazole Derivatives. II. Antiviral activity of 2-Phenylbenzimidazole derivatives. Bioorg. Med. Chem. 2010, 18, 2937-2953. [CrossRef]

18. Tonelli, M.; Paglietti, P.; Boido, V.; Sparatore, F.; Marongiu, F.; Marongiu, E.; La Colla, P.; Loddo, R. Antiviral activity of benzimidazole derivatives. I. Antiviral activity of 1-substituted-2-[(Benzotriazol-1/2-yl)methyl]benzimidazoles. Chem. Biodivers. 2008, 5, 2386-2401. [CrossRef]

19. Cichero, E.; Tonelli, M.; Novelli, F.; Tasso, B.; Delogu, I.; Loddo, R.; Bruno, O.; Fossa, P. Benzimidazole-based derivatives as privileged scaffold developed for the treatment of the RSV infection: A computational study exploring the potency and cytotoxicity profiles. J. Enzyme Inhib. Med. Chem. 2017, 32, 375-402. [CrossRef]

20. Paglietti, G.; Sparatore, F. Dialchilamminoalchilbenzimidazoli d'interesse farmacologico. III. Farmaco Ed. Sci. 1972, 27, 333-342.

21. Paglietti, G.; Boido, V.; Sparatore, F. Dialchilamminoalchilbenzimidazoli d'interesse farmacologico. IV. Farmaco Ed. Sci. 1975, 30, 505-511. 
22. Ali, A.A.; Nimir, H.; Aktas, C.; Huch, V.; Rauch, U.; Schäfer, K.-H.; Veith, M. Organoplatinum(II) complexes with 2-acetylthiophene thiosemicarbazone: Synthesis, characterization, crystal Structures, and in vitro antitumor activity. Organometallics 2012, 31, 2256-2262. [CrossRef]

23. Venkatachalam, T.K.; Pierens, G.K.; Reutens, D.C. Synthesis, NMR structural characterization and molecular modeling of substituted thiosemicarbazones and semicarbazones using DFT calculations to prove the syn/anti isomer formation. Magn. Reson. Chem. 2014, 52, 98-105. [CrossRef] [PubMed]

24. Vanderlinden, E.; Göktas, F.; Cesur, Z.; Froeyen, M.; Reed, M.L.; Russell, C.J.; Cesur, N.; Naesens, L. Novel inhibitors of influenza virus fusion: Structure-activity relationship and interaction with the viral hemagglutinin. J. Virol. 2010, 84, 4277-4288. [CrossRef] [PubMed]

25. Tonelli, M.; Naesens, L.; Gazzarrini, S.; Santucci, M.; Cichero, E.; Tasso, B.; Moroni, A.; Costi, M.P.; Loddo, R. Host dihydrofolate reductase (DHFR)-directed cycloguanil analogues endowed with activity against influenza virus and respiratory syncytial virus. Eur. J. Med. Chem. 2017, 135, 467-478. [CrossRef] [PubMed]

26. Francesconi, V.; Giovannini, L.; Santucci, M.; Cichero, E.; Costi, M.P.; Naesens, L.; Giordanetto, F.; Tonelli, M. Synthesis, biological evaluation and molecular modeling of novel azaspiro dihydrotriazines as influenza virus inhibitors targeting the host factor dihydrofolate reductase (DHFR). Eur. J. Med. Chem. 2018, 155, 229-243. [CrossRef]

27. Apaydın, Ç.B.; Cesur, N.; Stevaert, A.; Naesens, L.; Cesur, Z. Synthesis and anti-coronavirus activity of a series of 1-thia-4-azaspiro[4.5]decan-3-one derivatives. Arch. Pharm (Weinheim) 2019, 352, e1800330. [CrossRef]

28. Cianci, C.; Yu, K.L.; Combrink, K.; Sin, N.; Pearce, B.; Wang, A.; Civiello, R.; Voss, S.; Luo, G.; Kadow, K.; et al. Orally active fusion inhibitor of respiratory syncytial virus. Antimicrob. Agents Chemother. 2004, 48, 413-422. [CrossRef]

29. Meanwell, N.A.; Krystal, M. Respiratory syncytial virus-The discovery and optimization of orally bioavailable fusion inhibitors. Drugs Fut. 2007, 32, 441-455. [CrossRef]

30. Beigel, J.H.; Nam, H.H.; Adams, P.L.; Krafft, A.; Ince, W.L.; El-Kamary, S.S.; Sims, A.C. Advances in respiratory virus therapeutics - A meeting report from the 6th isirv Antiviral Group conference. Antiviral Res. 2019, 167, 45-67. [CrossRef]

31. Battles, M.B.; Langedijk, J.P.; Furmanova-Hollenstein, P.; Chaiwatpongsakorn, S.; Costello, H.M.; Kwanten, L.; Vranckx, L.; Vink, P.; Jaensch, S.; Jonckers, T.H.; et al. Molecular mechanism of respiratory syncytial virus fusion inhibitors. Nat. Chem. Biol. 2016, 12, 87-93. [CrossRef] [PubMed]

32. Roymans, D.; Alnajjar, S.S.; Battles, M.B.; Sitthicharoenchai, P.; Furmanova-Hollenstein, P.; Rigaux, P.; Berg, J.V.D.; Kwanten, L.; Ginderen, M.V.; Verheyen, N.; et al. Therapeutic efficacy of a respiratory syncytial virus fusion inhibitor. Nat. Commun. 2017, 8, 167. [CrossRef] [PubMed]

33. Waterbeemd, H.; Gifford, E. ADMET in silico modelling: Towards prediction paradise? Nat. Rev. Drug Discov. 2003, 2, 192-204. [CrossRef] [PubMed]

34. MOE: Gasteiger-Huckel method. Chemical Computing Group Inc. Montreal. H3A 2R7 Canada. Website: https://www.chemcomp.com/.

35. Böhm, H.J. The computer program LUDI: A new method for the de novo design of enzyme inhibitors. J. Comput. Aided Mol. Des. 1992, 6, 61-78. [CrossRef] [PubMed]

36. Böhm, H.J. The development of a simple empirical scoring function to estimate the binding constant for a protein-ligand complex of known three-dimensional structure. J. Comput. Aided Mol. Des. 1994, 8, 243-256. [CrossRef]

37. Rarey, M.; Kramer, B.; Lengauer, T.; Klebe, G. A fast flexible docking method using an incremental construction algorithm. J. Mol. Biol. 1996, 261, 470-489. [CrossRef]

38. Bichmann, L.; Wang, Y.T.; Fischer, W.B. Docking assay of small molecule antivirals to p7 of HCV. Comput. Biol. Chem 2014, 53, 308-317. [CrossRef]

39. Reulecke, I.; Lange, G.; Albrecht, J.; Klein, R.; Rarey, M. Towards an integrated description of hydrogen bonding and dehydration: Decreasing false positives in virtual screening with the HYDE scoring function. ChemMedChem. 2008, 3, 885-897. [CrossRef]

40. Schneider, N.; Hindle, S.; Lange, G.; Klein, R.; Albrecht, J.; Briem, H.; Beyer, K.; Claußen, H.; Gastreich, M.; Lemmen, C.; et al. Substantial improvements in large-scale redocking and screening using the novel HYDE scoring function. J. Comput. Aided Mol. Des. 2012, 26, 701-723. [CrossRef] 
41. Godha, K.; Hakoshima, T. A molecular mechanism of P-loop pliability of Rho-kinase investigated by molecular dynamic simulation. J. Comput. Aided Mol. Des. 2008, 22, 789-797.

42. Kolossváry, I.; Keseru, G.M. Hessian-Free Low-Mode Conformational Search for Large-Scale Protein Loop Optimization: Application to c-jun N-Terminal Kinase JNK3. J. Comput. Chem. 2001, 22, 21-30.

43. Labute, P. LowModeMD-Implicit Low-Mode Velocity Filtering Applied to Conformational Search of Macrocycles and Protein Loops. J. Chem. Inf. Model. 2010, 50, 792-800. [CrossRef] [PubMed]

44. Fossa, P.; Cichero, E. In silico evaluation of human small heat shock protein HSP27: Homology modeling, mutation analyses and docking studies. Bioorg. Med. Chem. 2015, 23, 3215-3220. [CrossRef] [PubMed]

45. Tonelli, M.; Espinoza, S.; Gainetdinov, R.R.; Cichero, E. Novel biguanide-based derivatives scouted as TAAR1 agonists: Synthesis, biological evaluation, ADME prediction and molecular docking studies. Eur. J. Med. Chem. 2017, 127, 781-792. [CrossRef]

46. Deiana, V.; Gómez-Cañas, M.; Pazos, M.R.; Fernández-Ruiz, J.; Asproni, B.; Cichero, E.; Fossa, P.; Muñoz, E.; Deligia, F.; Murineddu, G.; et al. Tricyclic pyrazoles. Part 8. Synthesis, biological evaluation and modelling of tricyclic pyrazole carboxamides as potential CB2 receptor ligands with antagonist/inverse agonist properties. Eur. J. Med. Chem. 2016, 112, 66-80. [CrossRef]

47. World Health Organization. Battle against Respiratory Viruses (BRaVe) initiative. Available online: http:/www.who.int/influenza/patient_care/clinical/brave/en/ (accessed on 14 June 2018).

48. World Health Organization. Research needs for the Battle against Respiratory Viruses (BRaVe). Available online: https://www.who.int/influenza/patient_care/clinical/BRaVe_Research_Agenda_2013.pdf (accessed on 14 June 2018).

49. World Health Organization. Novel Coronavirus (2019-nCoV) situation reports: Situation report-15. Available online: https://www.who.int/docs/default-source/coronaviruse/situation-reports/20200204-sitrep15-ncov.pdf?sfvrsn=88fe8ad6_4 (accessed on 4 February 2020).

50. De Clercq, E. Chemotherapy of respiratory syncytial virus infections: The final breakthrough. Int. J. Antimicrob. Agents 2015, 45, 234-237. [CrossRef]

Sample Availability: Samples of the compounds are available from the authors.

(C) 2020 by the authors. Licensee MDPI, Basel, Switzerland. This article is an open access article distributed under the terms and conditions of the Creative Commons Attribution (CC BY) license (http://creativecommons.org/licenses/by/4.0/). 